\title{
Parental education and child health: Evidence from a schooling reform
}

\author{
Maarten Lindeboom ${ }^{\mathrm{a}}$, Ana Llena-Nozal ${ }^{\mathrm{b}}$, Bas van der Klaauw ${ }^{\mathrm{c}, *}$ \\ a VU University Amsterdam, Tinbergen Institute, HEB \& Netspar, The Netherlands \\ b OECD, France \\ c VU University Amsterdam, Tinbergen Institute E' CEPR, The Netherlands
}

\section{A R T I C L E I N F O}

\section{Article history:}

Received 20 December 2006

Received in revised form 2 June 2008

Accepted 28 August 2008

Available online 7 September 2008

\section{JEL classification:}

C21

I12

I 21

Keywords:

Returns to education

Intergenerational mobility

Health

Regression-discontinuity

\begin{abstract}
A B S T R A C T
This paper investigates the impact of parental education on child health outcomes. To identify the causal effect we explore exogenous variation in parental education induced by a schooling reform in 1947, which raised the minimum school leaving age in the UK. Findings based on data from the National Child Development Study suggest that increasing the school leaving age by 1 year had little effect on the health of their offspring. Schooling did however improve economic opportunities by reducing financial difficulties among households.
\end{abstract}

(c) 2008 Elsevier B.V. All rights reserved.

\section{Introduction}

Studies have found that poor infant health persists into adulthood and that poor infant health contributes to the health income gradient found later in life (see Case et al., 2005; and the references cited therein). It is therefore important to examine which factors determine infant health. In this paper we look at the effect of parental education on child health.

There are different channels through which parental education can affect their children's health. Education might have a direct impact on child health because it increases the ability to acquire and process information. This helps parents to make better health investments for themselves and their children and may result in better parenting in general. Alternatively, education can affect child health through indirect pathways. An increased level of education can give access to more skilled work with higher earnings and these resources could be used to invest in health and to cushion the impact of adverse health shocks (Case et al., 2002). In the presence of assortative mating, individuals with a higher level of education also marry partners with higher levels of education, which positively affect family income. Case et al. (2002) find that parents' long run income is important for the child's health. Furthermore, attending school for a longer time could lead to a change in preferences by either lowering the discount rate or increasing risk-aversion (Cutler and Lleras-Muney, in press). Finally, increased education can increase the opportunity cost of having children and change fertility choices or delay having children. However, McCrary and Royer (2006) do not find any effect of mother's education on fertility choices.

\footnotetext{
* Corresponding author at: Department of Economics, Free University of Amsterdam, De Boelelaan 1105, 1081 HV Amsterdam, The Netherlands. Tel.: +3120 5986120; fax: +31205989870.

E-mail addresses: mlindeboom@econ.vu.nl (M. Lindeboom), ana.llena-nozal@oecd.org (A. Llena-Nozal), bklaauw@econ.vu.nl (B. van der Klaauw).
} 
While all these channels are potential explanations to why parental education might induce better child health, parental education and child health can also be related in non-causal ways. Indeed, endowments that are transmitted across generations can cause a positive association between parental education and child health. To overcome such endogeneity problems it is necessary to find some exogenous variation in parental education. Recently the use of schooling reforms as a source of exogenous variation has become popular in labor and health economics. Most industrialized countries have increased the statutory minimum age in the 20th century, with the aim to improve schooling attainments at the lower end of the educational distribution and to reduce inequality in schooling and subsequently in income. In a number of studies these reforms have been used to assess the causal impact of education on earnings (e.g. Harmon and Walker, 1995; Meghir and Palme, 2005; Pischke and von Wachter, 2008). The general conclusion from this literature is that more education increases income. Up to now there is little known about the effect of increases in education and socioeconomic outcomes on the health of those affected and of their offspring. There are some papers focusing on the effect of parental income on the education of their children (e.g. Black et al., 2005; Chevalier et al., 2005; Holmlund et al., 2008; Oreopoulos et al., 2006). A few papers have examined the impact of education on health. Oreopoulos (2006) uses changes in the minimum school leaving ages in the UK and Ireland and finds that an extra year of schooling increases earnings and improves self-assessed health when leaving school. Lleras-Muney (2005) uses variation across states in compulsory education laws and finds that an additional year of education lowers mortality. Using Danish panel data, Arendt (2005) finds inconclusive results of education on self-reported health and body mass index. He finds, however, that an increase in education reduces the probability that a person smokes. Currie and Moretti (2003) examine the impact of college openings on women's educational attainment and their infants' health. They find that maternal education does improve their offspring's health. Part of the effect is assigned to the increased use of prenatal care and reduced smoking. McCrary and Royer (2006) exploit discontinuities in school entry policies in California and Texas to assess the effect of education on fertility and infant health outcomes. They find that education does not affect observable inputs to infant health and has only small effects on infant health. Finally, Doyle et al. (2005) use a schooling reform and grandparental smoking behavior to instrument parental education and income and find no effect of parental income on the health of their offspring and weak effects of parental education. They conclude from this that the significant effects of parental income on child health as found in Case et al. (2002) and Currie et al. (2007) is spurious.

In this paper, we use a schooling reform that took place in the United Kingdom in 1947. The reform raised the minimum school leaving age from 14 to 15 . We show that the reform only affected the schooling decision of individuals at the lower end of the education distribution; the fraction of individuals leaving school at age 16 or later remained unaffected by the reform. More precisely, due to the reform about $50 \%$ of the individuals in a birth cohort raised their school leaving age from 14 to 15. We focus our empirical analyses mainly on those parents (fathers and mothers) leaving school at age 14 and $15 .{ }^{1}$ This means that the estimated impact of parental education should be considered as local average treatment effects (see Imbens and Angrist, 1994). We show that restricting the data increases the impact of the reform on schooling compared to using individuals with all levels of schooling as is done in previous studies. Previous approaches in this literature (e.g. Chevalier et al., 2005; Doyle et al., 2005; Oreopoulos, 2006) mostly included all schooling levels in the analyses, thereby implicitly assuming that reforms at the lower end of the education distribution also affect school leaving ages of those at the higher end of the education distribution. In the absence of such effects on the higher end of the education distribution this might lead to a weak instruments problem that will bias the results.

We assess the causal effect of parental education on a wide range of child health variables. These variables include health measured at birth as well as health measured later in childhood. This is important because finding an effect at birth (like in Currie and Moretti, 2003; for example) does not imply that the effect is long lasting. We discussed above that parental education might affect child health through different mechanisms. We therefore also examine whether parental education causally affects parental behavior, parental health and labor market outcomes of the parents. We find little effect of a direct causal relationship between parental education and child health. We also find that increased parental education does not affect parental health and parental behavior. However, we do find a significant causal effect of parental education on the families' financial resources. Increasing parental education reduces the probability that a family experiences financial hardship.

The remainder of this paper is organized as follows. In Section 2, we describe the dataset, and in Section 3 we discuss the background of the 1947 reform. Section 4 presents the empirical specification. The results are presented in Section 5 and we close with a discussion and conclusion in Section 6.

\section{Data}

The National Child Development Study is a longitudinal study of about 17,000 babies born in Great Britain in the week of 3-9 March 1958. The study started as the "Perinatal Mortality Survey" and surveyed the economic and obstetric factors associated with stillbirth and infant mortality. ${ }^{2}$ Since the first wave, cohort members have been traced on six other occasions to monitor their physical, educational and social circumstances. The interviews were carried out in 1965 (age 7), 1969 (age 11), 1974 (age 16), 1981 (age 23), 1991 (age 33) and 1999 (age 42). For the birth survey, information was gathered from the

\footnotetext{
1 This is in line with the approach taken by Black et al. (2005).

2 The survey includes only the children who have survived for the first few weeks. Observed child mortality is therefore very low and not related to socioeconomic characteristics.
} 
mother and medical records. For the surveys during childhood and adolescence, interviews were carried out with parents, teachers, and the school health service. The advantage of the National Child Development Study is that it contains information on both parents and children about education, health and other background characteristics.

The main indicators of health at birth are birth weight and an indicator for whether the child experienced an illness in the first week of life. We exclude twins from our sample since their birth weight is not comparable with singletons. Birth weight may not be linearly related to health at birth. In particular, a low birth weight is often considered as indication for bad health. Therefore, we also examine whether or not children have a low birth weight, defined as a birth weight below 3000 g. ${ }^{3}$ Illnesses at birth can be: incompatible Rh, severe jaundice, congenital malformation, convulsions (or cerebral irritation/cyanotic attacks), hypothermia, respiratory distress, infection, and pyloric stenosis. During later years in childhood and adolescence, parents are asked questions about their children's record of illnesses, psychological problems, accidents and hospitalizations. A medical examination is performed by a physician who records the child's specific medical problems. Using this information we develop several measures of child health. The first measure for morbidity is based on the number of conditions the child has experienced at ages 7, 11 and 16 (as reported by both parents and the physician). ${ }^{4}$ We use the total number of conditions as well as whether or not the child has a mental condition, a chronic condition or an acute condition. See the appendix for a definition of the latter three dichotomous variables. In addition, the survey contains information on the height and weight of the cohort members measured by a physician (and therefore less subject to measurement error than self-reports), which can be used to construct anthropometric indicators. Height-for-age-z-scores are built by comparing the height data with the distribution of height for a reference population, which is constructed by the US National Center for Health Statistics. Low height for age, or stunting, is an indicator of past growth failure and is associated with frequent or chronic illness, chronic inappropriate nutrition (insufficient energy intake and protein), and poverty. Height and weight are also used to construct the body mass index, which is a measure for overweight and thinness. We use the height-for-age- $z$ scores and the body mass index when the child was 7, 11 and 16. Health may be a non-linear function of body mass index and we therefore also use an indicator for overweight and underweight. Overweight of the child is defined in accordance with age and gender specific cut-off points in body mass index as defined in Cole et al. (2000). A child is underweight if it weighs less than 1 standard deviation of the weight for age $z$-score.

We know the year of birth of the parents and the age at which they left full-time education. In each wave we have information on the mother's working status and on whether the family experienced financial hardship. Information on family income is only observed when the child was 16 years old. The response rate for this variable was low and the variable appeared to be measured imprecisely. We therefore decided not to use this variable but instead use the response to a question on whether in the past 12 months the family was hit by serious financial hardship. This financial difficulties variable is measured at age 7, 11 and 16 . Financial difficulties are mostly temporary, about $62 \%$ of the families reporting financial difficulties at an interview, report at the next interview not to have financial difficulties anymore. This variable thus seems to reflect current income, rather than long-run income.

The National Child Development Study records parental weight and height when the child is 11 years old. This information can be transformed to obtain the body mass index. For the parents we also use an indicator for overweight and underweight in addition to the body mass index. A parent is defined to be overweight if the body mass index exceeds 25 and underweight if the body mass index is lower than 20. In addition, chronic conditions for the father and/or mother are recorded in all waves during childhood and adolescence. We use this information to construct a dummy for the presence of chronic conditions. These variables can be used as measures for parental health. Finally, we have some information about fertility since the birth survey contains a measure of parity (the number of times the mother has given birth until 1958) and on the number of siblings the cohort member has at each age.

Table 1 shows sample statistics of parental and child variables for different levels of parental education. For this study, we focus on the sample of cohort members who have both their natural parents between 1965 and 1974 . We observe that parents with more education have better socioeconomic and health outcomes. In particular, both more educated fathers and mothers report less financial difficulties and the prevalence of chronic conditions and obesity is lower among this group. Furthermore, all measures of child health are better for higher educated parents (lower probability of birth weight, illness at birth, serious conditions, stunting, under- and overweight). This shows the presence of the positive association between parental socioeconomic status and both parental and child health that is also found in other studies. Finally, higher educated parents less often smoke during pregnancy and provide more breastfeeding.

\section{Background of the 1947 reform and changes in schooling distribution}

\subsection{Description of the education reform}

The Education Act of 1944 changed the education system for secondary schools in England and Wales. It introduced a tripartite system whereby secondary schools were divided into: grammar schools (academic track), secondary technical and secondary modern schools. Students were allocated on the basis of an exam known as the "11 plus". It also made

\footnotetext{
3 Usually low birth weight is defined as a birth weight less than $2500 \mathrm{~g}$. However, this concerns only about $5 \%$ of sample and thus too few observations.

4 Following Power and Peckham (1987) we categorize the conditions under 12 groups (see Appendix).
} 
Table 1

Parental and child variables by level of parental schooling.

\begin{tabular}{|c|c|c|c|c|c|c|}
\hline & \multicolumn{3}{|l|}{ Fathers } & \multicolumn{3}{|c|}{ Mothers } \\
\hline & 14 & 15 & $16+$ & 14 & 15 & $16+$ \\
\hline Child birth weight (in kg) & 3.36 & 3.33 & 3.41 & 3.37 & 3.32 & 3.39 \\
\hline Being low birth weight (less than $3000 \mathrm{~g}$ ) (\%) & 24 & 24 & 18 & 23 & 25 & 20 \\
\hline Child has illness at birth (\%) & 3.0 & 2.2 & 2.4 & 3.2 & 2.6 & 2.1 \\
\hline Child number of conditions (average over $1965,1969,1974$ ) & 2.17 & 2.16 & 2.07 & 2.15 & 2.22 & 2.10 \\
\hline Child has chronic condition (\%) & 49 & 48 & 46 & 49 & 50 & 45 \\
\hline Child has mental condition (\%) & 43 & 42 & 38 & 43 & 43 & 39 \\
\hline Child has acute condition (\%) & 60 & 61 & 58 & 60 & 62 & 58 \\
\hline Height-for-age $z$-score & -0.098 & -0.078 & 0.037 & -0.077 & -0.108 & 0.077 \\
\hline Body mass index (average over $1965,1969,1974$ ) & 18.1 & 17.9 & 17.6 & 18.1 & 17.9 & 17.6 \\
\hline Underweight ( $<1$ S.D. of $z$-score) $(\%)$ & 17.5 & 18.1 & 13.7 & 17.1 & 19.0 & 13.1 \\
\hline Overweight (\%) & 10.7 & 8.7 & 8.9 & 11.2 & 8.8 & 8.7 \\
\hline Maternal smoking during pregnancy (\%) & 36 & 31 & 23 & 37 & 33 & 21 \\
\hline Breastfeeding (\%) & 67 & 74 & 79 & 65 & 74 & 79 \\
\hline Father chronic conditions (average over 1969, 1974) (\%) & 8.3 & 4.8 & 4.0 & 8.6 & 5.6 & 4.5 \\
\hline Mother chronic conditions (average over 1969,1974 ) (\%) & 6.2 & 5.6 & 4.2 & 6.7 & 5.4 & 4.3 \\
\hline Body mass index father & 24.3 & 24.3 & 24.0 & 24.4 & 24.2 & 24.0 \\
\hline Father underweight (body mass index below 20) (\%) & 6.1 & 5.9 & 5.5 & 6.3 & 6.0 & 5.5 \\
\hline Father overweight (body mass index above 25 ) (\%) & 37.6 & 37.5 & 30.9 & 38.4 & 36.9 & 30.5 \\
\hline Body mass index mother & 23.7 & 23.1 & 22.6 & 23.7 & 23.1 & 22.7 \\
\hline Mother underweight (body mass index below 20) (\%) & 18.9 & 21.4 & 22.2 & 18.4 & 22.1 & 21.3 \\
\hline Mother overweight (body mass index above 25 ) (\%) & 30.9 & 25.5 & 17.5 & 32.1 & 25.0 & 18.4 \\
\hline Mother works (average over 1965, 1969, 1974) (\%) & 53 & 60 & 49 & 58 & 59 & 54 \\
\hline Financial difficulties in the family (average over $1965,1969,1974)(\%)$ & 9.6 & 9.8 & 3.1 & 10.6 & 9.8 & 3.9 \\
\hline
\end{tabular}

secondary education free for all. The aims of the education reform were to "improve the future efficiency of the labor force, increase physical and mental adaptability, and prevent the mental and physical cramping caused by exposing children to monotonous occupations at an especially impressionable age" (Oreopoulos, 2006). In addition, the Act resulted in the raising of the minimum school-leaving age from 14 to 15 in April 1947. According to Galindo-Rueda (2003), the reform brought about an increase in the number of pupils that was largely concentrated among the secondary modern and technical schools where there were few entry requirements based on ability.

\subsection{Distribution of schooling before and after the reform in the National Child Development Study data}

The National Child Development Study includes parents born at different dates who are therefore affected differently by the reform. The first cohort of parents that is affected by the reform is born in 1934; they had to stay in school until the age of 15 , compared to 14 for previous cohorts. Fig. 1 shows the mean age of finishing school by year of birth for fathers and mothers. The mean age experiences a sharp raise in 1934, showing that the reform raised schooling age by on average 3 months for fathers and 4.5 months for mothers. Previous to the reform fathers' education reached a peak in 1930 and started to decline while mother's education declined later, in 1932. This is due to the fact that fathers tend to be older than mothers in our sample (see frequency of birth years in Table 2). In addition, after the original increase caused by the reform we observe a decrease in the mean age of schooling. Note that these are parents who had a child in 1958 and that less educated individuals

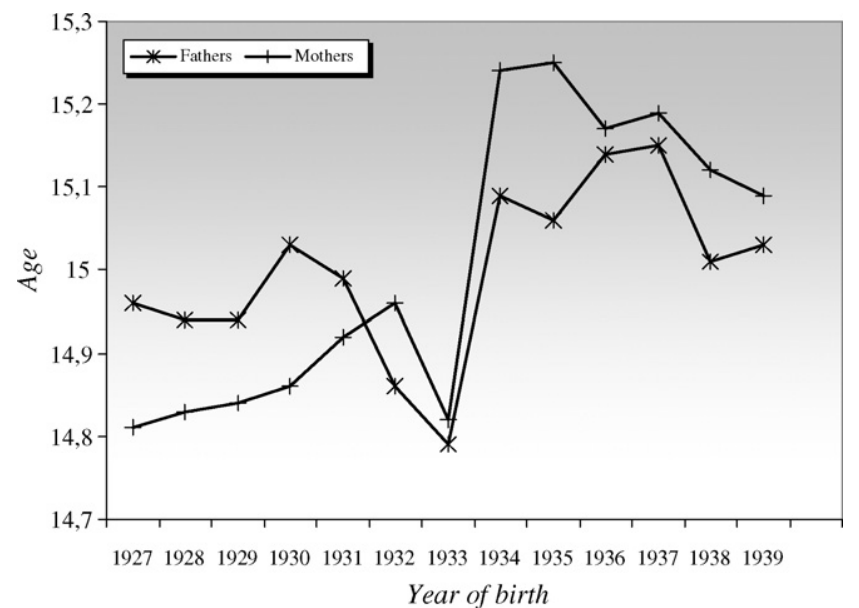

Fig. 1. Mean age of finishing schooling by birth year 
Table 2

Distribution of parents schooling by year of birth.

\begin{tabular}{|c|c|c|c|c|c|c|}
\hline & \multicolumn{3}{|c|}{ Fathers } & \multicolumn{3}{|c|}{ Mothers } \\
\hline & Mean & S.D. & Freq. & Mean & S.D. & Freq. \\
\hline 1927 & 14.96 & 2.11 & 1644 & 14.81 & 1.74 & 1254 \\
\hline 1928 & 14.94 & 1.93 & 1947 & 14.83 & 1.64 & 1557 \\
\hline 1929 & 14.94 & 2.00 & 2019 & 14.84 & 1.67 & 1905 \\
\hline 1930 & 15.03 & 2.03 & 2133 & 14.86 & 1.62 & 1857 \\
\hline 1931 & 14.99 & 1.92 & 1989 & 14.92 & 1.71 & 2316 \\
\hline 1932 & 14.86 & 1.62 & 1977 & 14.96 & 1.71 & 2040 \\
\hline 1933 & 14.79 & 1.65 & 1785 & 14.82 & 1.39 & 2055 \\
\hline 1934 & 15.09 & 1.35 & 1500 & 15.24 & 1.29 & 2019 \\
\hline 1935 & 15.06 & 0.94 & 1305 & 15.25 & 1.04 & 1986 \\
\hline 1936 & 15.14 & 1.14 & 966 & 15.17 & 0.98 & 1860 \\
\hline 1937 & 15.15 & 1.08 & 588 & 15.19 & 0.87 & 1608 \\
\hline 1938 & 15.01 & 0.73 & 330 & 15.12 & 0.68 & 1245 \\
\hline 1939 & 15.03 & 0.74 & 174 & 15.09 & 0.65 & 744 \\
\hline
\end{tabular}

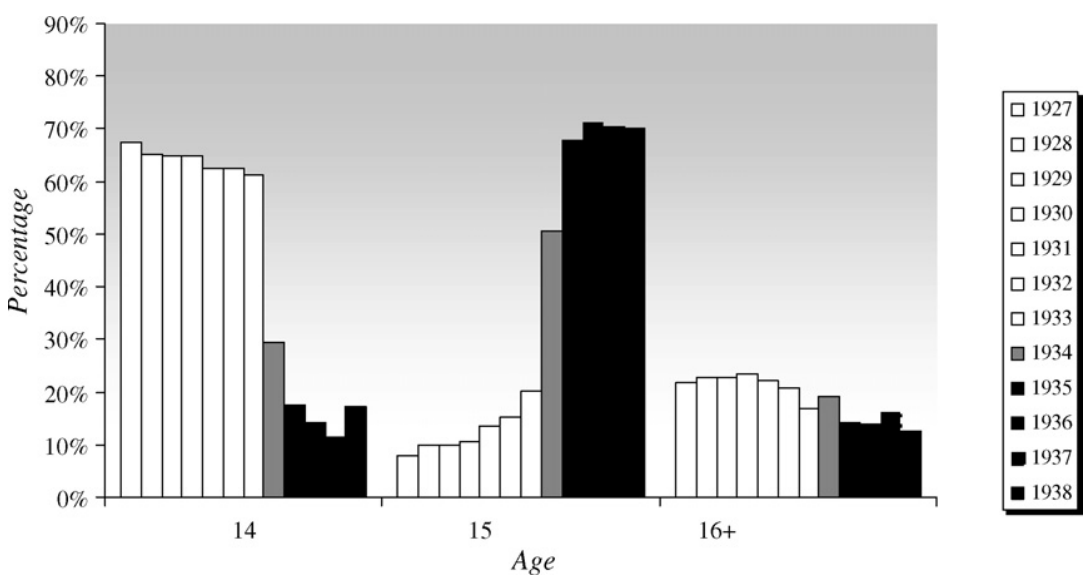

Fig. 2. Age finishing school by year of birth (fathers). The white bars describe the pre-reform period, the grey bar is the reform year and the black bars are the post-reform years.

are more likely to have children at young ages. This can lead to a sample where older individuals are more likely to have more education.

Figs. 2 and 3 depict the percentages of parents leaving school at each age (stratified according to their year of birth). We see that prior to the reform more than $60 \%$ of the population left school at age 14 while between 10 and $20 \%$ (depending

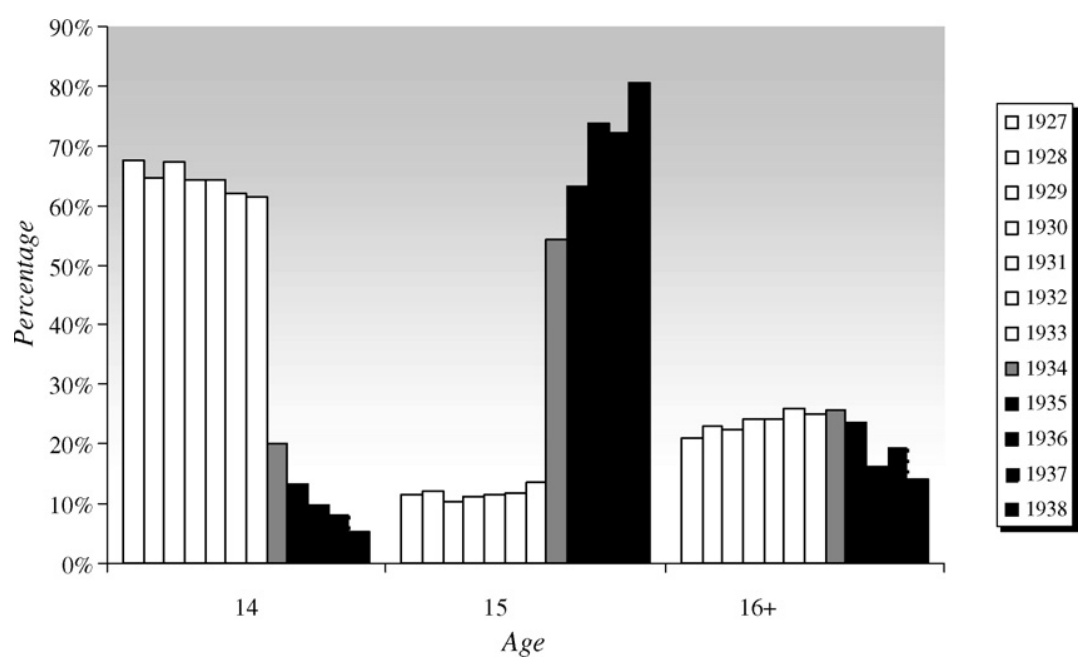

Fig. 3. Age finishing school by year of birth (mothers). The white bars describe the pre-reform period, the grey bar is the reform year and the black bars are the post-reform years. 
Table 3

Effect of the reform of school leaving age.

\begin{tabular}{|c|c|c|c|c|}
\hline & \multicolumn{2}{|l|}{ Father } & \multicolumn{2}{|l|}{ Mother } \\
\hline & Full sample & Restricted sample & Full sample & Restricted sample \\
\hline \multicolumn{5}{|l|}{ All years } \\
\hline Born in 1934 & $0.147(0.064)^{* *}$ & $0.477(0.024)^{* *}$ & $0.407(0.053)^{* *}$ & $0.555(0.020)^{* *}$ \\
\hline Born in 1935 and afterwards & $0.145(0.036)^{* *}$ & $0.671(0.013)^{* *}$ & $0.323(0.025)^{* *}$ & $0.708(0.008)^{* *}$ \\
\hline Observations & 11,072 & 8389 & 11,274 & 8593 \\
\hline \multicolumn{5}{|l|}{ 1930-1938 } \\
\hline Born in 1934 & $0.176(0.070)^{* *}$ & $0.443(0.026)^{* *}$ & $0.355(0.058)^{* *}$ & $0.573(0.021)^{* *}$ \\
\hline Born in 1935 and afterwards & $0.182(0.047)^{* *}$ & $0.628(0.015)^{* *}$ & $0.292(0.036)^{* *}$ & $0.721(0.011)^{* *}$ \\
\hline Observations & 4186 & 3342 & 5669 & 4350 \\
\hline \multicolumn{5}{|l|}{ 1931-1937 } \\
\hline Born in 1934 & $0.218(0.072)^{* *}$ & $0.425(0.026)^{* *}$ & $0.347(0.061)^{* *}$ & $0.570(0.022)^{* *}$ \\
\hline Born in 1935 and afterwards & $0.235(0.052)^{* *}$ & $0.613(0.017)^{* *}$ & $0.299(0.042)^{* *}$ & $0.704(0.013)^{* *}$ \\
\hline Observations & 3365 & 2806 & 4625 & 3527 \\
\hline \multicolumn{5}{|l|}{ 1933-1935 } \\
\hline Born in 1934 & $0.297(0.090)^{* *}$ & $0.383(0.031)^{* *}$ & $0.424(0.072)^{* *}$ & $0.552(0.026)^{* *}$ \\
\hline Born in 1935 and afterwards & $0.266(0.081)^{* *}$ & $0.544(0.029)^{* *}$ & $0.423(0.066)^{* *}$ & $0.644(0.024)^{* *}$ \\
\hline Observations & 1530 & 1258 & 2024 & 1508 \\
\hline \multicolumn{5}{|l|}{ 1930-1938 excluding 1934} \\
\hline Born in 1935 and afterwards & $0.182(0.047)^{* *}$ & $0.628(0.015)^{* *}$ & $0.292(0.036)^{* *}$ & $0.721(0.011)^{* *}$ \\
\hline Observations & 3686 & 2924 & 4996 & 3854 \\
\hline
\end{tabular}

Robust standard errors in parentheses; *Significant at 10\% level; **Significant at 5\% level.

on the year and gender) left at age 15 . Within 2 years after the reform, close to $70 \%$ of fathers and mothers left at age 15 . The graphs show that the proportion leaving at age 16 and beyond remains similar before and after the implementation of the new minimum school leaving age. It therefore appears that the reform primarily affected those who would have left school earlier in absence of the reform. In 1934 only about $50 \%$ finished school at age 15 (55\% for mothers), while $20 \%$ of mothers and $30 \%$ of fathers stayed until age 14 only. This is most likely due to partial implementation of the reform or to pupils turning 14 before the reform was fully passed. Since we do not have the exact date of birth we cannot check either hypothesis. Galindo-Rueda (2003) investigated whether behavioral responses to the reform varied according to observable characteristics. He found that mothers from smaller families and with skilled or semi-skilled parents were more likely to increase their schooling (the response was not heterogeneous for fathers).

We estimate the effect of the reform on the age at which fathers and mothers leave school. We capture the effect of the reform by a dummy for whether the individual was 14 on the year the reform was implemented and on the subsequent years it was in place. Since the reform might not fully affect the 1934 cohort like the later birth cohorts, we look at the effect of being born in 1934 and of being born in 1935 and afterwards. Additionally, for comparison purposes, we re-estimate the same model excluding those born in 1934. We perform the regressions for different birth year intervals and we also compare the effect on the entire education distribution (full sample) and only those finishing at ages 14 and 15 (restricted sample). The results are reported in Table 3 and show that the education reform had a stronger impact on the restricted sample of lower educated individuals. For the restricted sample both the coefficients are higher and the standard errors are lower. For the full sample, covering all educational levels, the reform in 1947 increased the mother's education by 0.407 years. The increase for the lower educated mothers ("restricted sample") was 0.555 years. For males this difference was even bigger (the coefficient increased from 0.147 to 0.477 ). This indeed confirms that the reform mainly affected the educational choices of those individuals at the lower end of the educational distribution. Furthermore, there seems to be some sensitivity of the reform's impact to the sample of birth cohorts chosen. When looking at all education ages, it appears that the reform had a slightly larger effect for those born in 1934. The reverse is true for the sample of people leaving at ages 14 and 15: those born in 1935 and afterwards experienced a greater increase in education than those born in 1934. In addition, the effect of the reform slightly decreases as birth cohorts closer in time are taken into account. The effect of the reform on educational attainment is the first-stage of our model. In Section 5 we investigate the predictive power of the reform in the different sample further by considering $F$-test for significance of the reform.

\section{Estimation methods}

The schooling reform provides a natural experiment that can be used to identify the causal impact of parental schooling on a number of different outcome measures. Since close to the reform individuals are expected to be similar except for exposure to the reform, we can use regression-discontinuity techniques. The design is fuzzy, as the school leaving age does not deterministically depend on exposure to the reform (e.g. Hahn et al., 2001). Obviously prior to the reform some individuals left school at age 15 or later, but also after the reform still some individuals left school at age 14 . Since exposure to the reform depends on the year of birth, the regression-discontinuity design suggests that we should compare individuals born close to 
1934, which was the first birth cohort affected by the reform. In the fuzzy regression-discontinuity design parental education is instrumented by whether or not they were exposed to the reform. Our empirical model is summarized by the following three equations:

$$
\begin{aligned}
& H=\beta_{0}+\beta_{1} E^{\mathrm{f}}+\beta_{2} E^{\mathrm{m}}+\beta_{3} S+\beta_{4} P+\beta_{5} R+\beta_{6} A^{\mathrm{f}}+\beta_{7} A^{\mathrm{m}}+\varepsilon \\
& E^{\mathrm{f}}=\delta_{0}+\delta_{1} Y^{\mathrm{f}}+\delta_{2} S+\delta_{3} P+\delta_{4} R+\delta_{5} A^{\mathrm{f}}+\gamma \\
& E^{\mathrm{m}}=\delta_{0}+\delta_{1} Y^{\mathrm{m}}+\delta_{2} S+\delta_{3} P+\delta_{4} R+\delta_{5} A^{\mathrm{m}}+v
\end{aligned}
$$

$H$ represents child health, $E$ the age at which the father and mother finished school, $S$ the sex of the child, $P$ parity in 1958 , $R$ includes dummy variables for the region of residence, $A$ includes the age of the father and the mother in 1958 , and $Y$ is a dummy for whether the individual was affected by the reform. The superscript $\mathrm{f}$ indicates that the variable relates to the father, while the superscript m relates to the mother.

An important reason for including parity of the child and parental age is to reduce potential biases that might arise because the sample consists of families having a child born in 1958. It cannot be ruled out that the schooling reform affects fertility decisions such as the timing of childbearing and/or the number of children. We have checked the effect of the reform on parity in 1958 and on total fertility as observed in the 1974 survey and we did not find a significant or substantial effect of the reform in these regressions. Nevertheless, it is possible that the reform affects the decision to have any children at all or to delay childbearing. Furthermore, parents affected by the reform were born in later years than parents not affected by the reform. This implies that the parents affected by the reform were younger in 1958 when the child was born. We expect that controlling for parity and parental age reduces potential biases, but we cannot rule out that some biases remain. It has to be noted that the same criticism applies to the study by McCrary and Royer (2006) who condition on mothers having their first child before age 23 .

This model will estimate the causal effects of parental education on a range of child health variables: the child's birth weight, being low birth weight, whether the child had an illness at birth, the number of conditions in later childhood, the occurrence of chronic, mental and acute conditions, height-for-age-z-scores, body mass index, being overweight and being underweight. The results of these analyses will be discussed in Section 5.1.

As mentioned earlier, the impact of parental education may act on child health through various channels. Firstly, it may be that higher educated parents have more knowledge about prenatal care and care-taking of children and therefore for example they smoke less during pregnancy or more often breastfeed their child. Secondly, it is possible that increased education may have a direct impact on parents' health and that better parental health is transmitted across generations. Thirdly, health benefits might come from increased earnings or changed labor supply choices (particularly for women). We will also examine whether there is a causal effect of education on parental outcome variables such as: maternal smoking, whether the child was breastfed, indicators for chronic conditions for the father and mother, father's and mother's body mass index, and whether the parents were underweight or overweight, the work status of the mother and whether the family experienced financial difficulties. The results of these analyses will be discussed in Section 5.2.

Identification from the regression-discontinuity design assumes that the population affected by the reform and the population not affected by the reform differ only in exposure to the reform. In practice, this assumption is justified only if the sample consists of birth cohorts sufficiently close to 1934 in order to avoid other cohort and trend effects. Indeed, children born to older parents might face a different socioeconomic environment than those born to younger parents, which might affect the outcomes of interest. We estimate our model for different subsamples of birth cohorts. It is obvious that if we restrict the subsample to only a few birth cohorts, we have a relatively small sample size. On the other hand if we take a subsample with many birth cohorts, other cohort and trend effects might bias the estimated effects. When restricting to a subsample of particular birth cohorts, we include only families with both parents born in the included birth years. As mentioned in the previous subsection, in 1934 there might have been only partial compliance to the reform. Therefore, as instrumental variables in Eqs. (2) and (3), we include separate dummy variables for being born in 1934 and for being born in 1935 or later. Furthermore, we construct subsamples from which we exclude families with parents born in 1934. As mentioned in the previous section, the reform only affected the behavior of those individuals for whom the reform was binding. The fraction of individuals leaving school at age 16 or later did not change due to the reform. We estimate our model both for the full sample containing individuals with all levels of education and a restricted sample containing only individuals who left school at age 14 or 15 . The interpretation of the coefficients $\beta_{1}$ and $\beta_{2}$ differs between both sample choices. In case we use the full sample, the coefficients describe homogenous effects of education. We have shown that the reform affected only individuals in the lower part of the educational distribution. This implies that if we use the full sample, the linear first stage regressions ( 2 ) and (3) are wrongly specified. If we use the restricted sample, the coefficients $\beta_{1}$ and $\beta_{2}$ should be interpreted as local effect of schooling, since these coefficient only measure educational effects for those parents persuaded to obtain one additional year of education due to the reform. Under the assumption that no individual will lower his/her level of education due to the reform (monotonicity assumption), our estimated effects should be interpreted within the local average treatment effect framework (Imbens and Angrist, 1994). In particular, this implies that our estimated effects are the educational effects for those individuals who due to the reform increased their school leaving age from 14 to 15 . From the previous section we have seen that this is about $50 \%$ of a birth cohort. The results are nevertheless interesting from a policy point of view because they focus on those at the bottom of the education distribution, the same group that is often aimed at in public programs. 


\section{Results}

\subsection{Child health}

The OLS estimation results for Eq. (1) are presented in Tables 4a (results for the full sample) and 4b (the results for parents finishing school at age 14 or 15). The tables include the effect of parental education on infant health at the time of birth and health at later ages in childhood. We include the coefficients of father's and mother's education as well as the $p$-value for joint significance of these two variables. The OLS estimates show significant associations between parental education and indicators for their offspring's birth weight. More parental education is associated with a higher birth weight and a lower probability of being observed as having a low birth weight. The coefficients become larger when we consider the restricted sample. The latter implies that at the lower end of the educational distribution the association between birth weight and parental education is stronger. We do not find such an association for an illness at birth (the restricted sample of less educated parents born in 1933-1935 being the exception).

For later childhood health, the full sample shows a positive association between parental schooling and child health when looking at anthropometric measures. Both maternal and paternal education levels are associated with higher height-for-age$z$-scores for children. When we focus on fewer birth cohorts around the year of the reform, we find only maternal education to be significantly positively correlated with higher height-for-age-z-scores. The father's education is associated to a lower body mass index and a lower probability of being overweight. Mother education is positively correlated to body mass index and a smaller probability of being underweight. It should be noted that most of these associations lose significance when considering only the restricted sample of lower educated parents. For both the full and the restricted sample, we do not find significant associations between father's and mother's education and the number of conditions during later childhood (ages $7,11,16)$. We occasionally find some effects of parental education on the separate indicators for chronic, acute and mental condition, but the general picture is that there is little relation between these variables and parental education.

Tables $5 a$ (full sample) and $5 b$ (restricted sample) presents the estimation results from instrumental variables (IV) regression. Recall that the age at which the parents left school is instrumented by whether they were affected by the reform. In the tables we not only show the estimated coefficients for mother's and father's education and the $p$-value for joint significance, but we also include $F$-test for joint significance of the instruments in the first stage regression. Staiger and Stock (1997) argue that the estimators may be biased due to weak instruments problems if the F-test for joint significance does not exceed 10 . The results of the F-tests indicate that for the full sample (Table $5 \mathrm{a}$ ) weak instruments problems may arise. However, when focusing only on the lower end of the education distributions, the F-tests are far larger than 10 (see Table $5 \mathrm{~b}$ ). This is in line with the findings of Table 3 (discussed in Section 3) where we concluded that the effect of the reform is strongest for those at the lower end of the education distribution. This also suggests that the effects of education reforms should only be evaluated at the part of the education distribution where the compulsory school leaving age is binding. Almost all results presented in Tables 5a and 5b are statistically insignificant, suggesting that there is no substantial causal effect of increased parental education on infant health and health in later childhood. For the sample of parents leaving school at age 14-15 we find only that father's education has a marginally significant effect on the probability of having an illness at birth. But this effect is only present in the subsample of the birth cohorts 1931-1937 and disappears in the other subsamples. ${ }^{5}$

Epidemiological and economic studies on the long-run effects of poor infant health often find different results for boys and girls. For instance, Leon et al. (1998) find that the relationship between birth weight and death from ischaemic heart disease is significant for men and not for women. Similarly, Van den Berg et al. (2006) find that being born in a recession increases mortality risk at later ages and that this effect is only significant for men. We therefore also perform separate IV analyses for boys and girls. This did not alter the results. In none of the analyses we found significant effects of parental education on the infant's health.

In the economic literature intergenerational effects are most often estimated separately for fathers and mothers (Black et al., 2005; Holmlund et al., 2008). The interpretation of the coefficients of education in separate regressions differs from those in our model where both father's and mother's education are included. In particular, when separate regressions are done for the father and mother, the estimated effects also include the effects of whom he/she marries (Behrman and Rosenzweig, 2002). Effects of assortative mating on education are thus included in the parameter estimate of the education coefficient when one performs separate regressions for both parents. In a model where the education of both parents is included one can interpret the results as the direct effects of each parents' education. However, more importantly, performing separate analyses for fathers and mothers can lead to inconsistent estimates in the case of assortative mating, even if one performs IV analyses. The main reasoning behind this is that if the father and mother are close in age, the reform is not a valid instrumental variable anymore. If one parent is affected by the reform, this increases the probability that also the partner is also affected by the reform. Therefore, the increased education of the partner does not only run via the educational level of the parent, but also via the reform. Since the educational level of the partner is not included as regressor, it is absorbed in the error term of the second stage. Assortative matching on age thus causes that the variables describing the reform are correlated with the second-stage error terms, which violates the validity condition for instrumental variables. Our data shows that the

\footnotetext{
${ }^{5}$ A Bonferroni correction for statistical significance would lead to fewer significant outcomes. However, applying the Bonferroni correction might be problematic as some of the outcomes non-linear functions of each other, for example birth weight and being low birth weight.
} 
Table 4a

Parents education and child's health-OLS results (full sample).

\begin{tabular}{|c|c|c|c|c|c|c|c|c|c|c|c|}
\hline & Birth weight & $\begin{array}{l}\text { Low birth } \\
\text { weight }\end{array}$ & Illness at birth & $\begin{array}{l}\text { Number of } \\
\text { conditions }\end{array}$ & $\begin{array}{l}\text { Having a } \\
\text { chronic } \\
\text { condition }\end{array}$ & $\begin{array}{l}\text { Having a } \\
\text { mental } \\
\text { condition }\end{array}$ & $\begin{array}{l}\text { Having an } \\
\text { acute } \\
\text { condition }\end{array}$ & $\begin{array}{l}\text { Height-for } \\
\text { age-z scores }\end{array}$ & $\begin{array}{l}\text { Body mass } \\
\text { index }\end{array}$ & Underweight & Overweight \\
\hline \multicolumn{12}{|l|}{ 1930-1938 } \\
\hline Father & $0.007(0.006)$ & $-0.011(0.006)^{*}$ & $0.000(0.002)$ & $0.000(0.015)$ & $0.007(0.005)$ & $-0.005(0.004)$ & $0.003(0.005)$ & $0.028(0.013)^{* *}$ & $-0.040(0.026)$ & $-0.001(0.004)$ & $-0.003(0.003)$ \\
\hline Mother & $0.020(0.008)^{* *}$ & $-0.011(0.007)$ & $-0.001(0.003)$ & $-0.014(0.021)$ & $0.000(0.006)$ & $-0.002(0.006)$ & $-0.012(0.007)^{*}$ & $0.039(0.016)^{* *}$ & $-0.002(0.034)$ & $-0.008(0.005)^{*}$ & $-0.005(0.003)$ \\
\hline$P$-value joint & 0.000 & 0.001 & 0.951 & 0.725 & 0.314 & 0.331 & 0.216 & 0.000 & 0.150 & 0.054 & 0.029 \\
\hline Observations & 3331 & 3331 & 3459 & 8186 & 8514 & 8929 & 8961 & 7921 & 7921 & 7921 & 7921 \\
\hline \multicolumn{12}{|l|}{ 1931-1937 } \\
\hline Father & $0.005(0.007)$ & $-0.009(0.007)$ & $-0.003(0.002)$ & $-0.009(0.018)$ & $0.002(0.006)$ & $-0.004(0.005)$ & $0.003(0.006)$ & $0.026(0.015)^{*}$ & $-0.085(0.029)^{* *}$ & $-0.001(0.004)$ & $-0.007(0.003)^{* *}$ \\
\hline Mother & $0.018(0.010)^{*}$ & $-0.008(0.009)$ & $0.001(0.003)$ & $-0.021(0.025)$ & $-0.003(0.008)$ & $-0.006(0.007)$ & $-0.020(0.008)^{* *}$ & $0.042(0.019)^{* *}$ & $0.029(0.041)$ & $-0.009(0.005)^{* *}$ & $-0.002(0.004)$ \\
\hline$P$-value joint & 0.023 & 0.081 & 0.496 & 0.367 & 0.937 & 0.253 & 0.036 & 0.000 & 0.008 & 0.019 & 0.013 \\
\hline Observations & 2345 & 2345 & 2434 & 5740 & 5964 & 6249 & 6270 & 5543 & 5543 & 5543 & 5543 \\
\hline \multicolumn{12}{|l|}{ 1933-1935 } \\
\hline Father & $0.014(0.017)$ & $-0.024(0.016)$ & $0.009(0.006)$ & $-0.057(0.043)$ & $-0.009(0.014)$ & $-0.009(0.011)$ & $0.004(0.014)$ & $0.018(0.027)$ & $-0.171(0.058)^{* *}$ & $-0.005(0.007)$ & $-0.014(0.006)^{* *}$ \\
\hline Mother & $0.013(0.019)$ & $-0.008(0.018)$ & $-0.008(0.007)$ & $0.001(0.054)$ & $0.002(0.015)$ & $0.004(0.013)$ & $-0.032(0.018)^{*}$ & $0.080(0.034)^{* *}$ & $0.165(0.080)^{* * *}$ & $-0.007(0.009)$ & $0.006(0.010)$ \\
\hline$P$-value joint & 0.396 & 0.134 & 0.311 & 0.344 & 0.755 & 0.700 & 0.182 & 0.008 & 0.011 & 0.293 & 0.108 \\
\hline Observations & 543 & 543 & 561 & 1321 & 1382 & 1445 & 1450 & 1288 & 1288 & 1288 & 1288 \\
\hline \multicolumn{12}{|c|}{ 1930-1938, excluding 1934} \\
\hline Father & $0.000(0.007)$ & $-0.012(0.006)^{*}$ & $0.000(0.002)$ & $0.017(0.017)$ & $0.012(0.006)^{* *}$ & $-0.005(0.005)$ & $0.008(0.006)$ & $0.023(0.015)$ & $-0.058(0.028)^{* *}$ & $0.002(0.005)$ & $-0.004(0.003)$ \\
\hline Mother & $0.028(0.009)^{* *}$ & $-0.011(0.008)$ & $-0.002(0.003)$ & $-0.024(0.022)$ & $-0.005(0.007)$ & $-0.002(0.006)$ & $-0.131(0.008)$ & $0.047(0.018)^{* *}$ & $0.006(0.039)$ & $-0.011(0.006)^{*}$ & $-0.005(0.004)$ \\
\hline$P$-value joint & 0.002 & 0.005 & 0.785 & 0.487 & 0.086 & 0.358 & 0.245 & 0.000 & 0.042 & 0.101 & 0.024 \\
\hline Observations & 2532 & 2532 & 2612 & 6221 & 6461 & 6778 & 6804 & 6032 & 6032 & 6032 & 6032 \\
\hline
\end{tabular}

Robust standard errors in parentheses: *Significant at $10 \%$ level: **Significant at $5 \%$ level. For each interval, both the mother and the father are born within those years. Regressions are performed for children livin with their natural parents and include sex of child, parity, regional dummies, and parental age. The results for the number of conditions, height-for age- $z$ scores and body mass index are based on observations when the child was 7, 11 and 16 years old. We control for the age of the child and the estimation includes clustered standard errors. Disaggregated analyses are available upon request. 
Table 4b

Parents education and child's health-OLS results (Parents finishing at age 14-15).

\begin{tabular}{|c|c|c|c|c|c|c|c|c|c|c|c|}
\hline & $\begin{array}{l}\text { Birth } \\
\text { weight }\end{array}$ & $\begin{array}{l}\text { ow birth } \\
\text { weight }\end{array}$ & $\begin{array}{l}\text { Illness at } \\
\text { birth }\end{array}$ & $\begin{array}{l}\text { Number of } \\
\text { conditions }\end{array}$ & $\begin{array}{l}\text { Having a } \\
\text { chronical } \\
\text { condition }\end{array}$ & $\begin{array}{l}\text { Having a } \\
\text { mental } \\
\text { condition }\end{array}$ & $\begin{array}{l}\text { Having an } \\
\text { acute } \\
\text { condition }\end{array}$ & $\begin{array}{l}\text { Height-for } \\
\text { age-z } \\
\text { scores }\end{array}$ & $\begin{array}{l}\text { Body mass } \\
\text { index }\end{array}$ & Underweight & Overweight \\
\hline \multicolumn{12}{|l|}{$1930-1938$} \\
\hline Father & $0.084(0.026)^{* *}$ & $-0.071(0.023)^{* *}$ & $0.008(0.008)$ & $-0.110(0.069)$ & $-0.023(0.021)$ & $-0.038(0.019)^{* *}$ & $-0.005(0.022)$ & 0.073 & $0.049(0.109)$ & $-0.032(0.017)^{*}$ & $0.004(0.012)$ \\
\hline Mother & $-0.035(0.029)$ & $0.003(0.026)$ & $-0.008(0.009)$ & $-0.011(0.075)$ & $-0.024(0.022)$ & $-0.017(0.020)$ & $0.021(0.024)$ & $-0.062(0.057)$ & $-0.085(0.119)$ & $0.024(0.019)$ & $-0.018(0.013)$ \\
\hline$P$-value joint & 0.006 & 0.006 & 0.515 & 0.238 & 0.176 & 0.045 & 0.680 & 0.314 & 0.752 & 0.120 & 0.426 \\
\hline Observations & 2287 & 2287 & 2381 & 5609 & 5845 & 6152 & 6175 & 5415 & 5415 & 5415 & 5415 \\
\hline \multicolumn{12}{|l|}{ 1931-1937 } \\
\hline Father & $0.080(0.030)^{* *}$ & $-0.087(0.027)^{* *}$ & $0.005(0.010)$ & $-0.116(0.085)$ & $-0.032(0.025)$ & $-0.041(0.022)^{*}$ & $-0.008(0.027)$ & $0.046(0.062)$ & $-0.035(0.131)$ & $-0.018(0.020)$ & $0.002(0.014)$ \\
\hline Mother & $-0.015(0.033)$ & $0.000(0.030)$ & $-0.001(0.010)$ & $-0.021(0.091)$ & $-0.032(0.026)$ & $-0.018(0.024)$ & $0.037(0.028)$ & $-0.037(0.066)$ & $-0.117(0.144)$ & $0.025(0.021)$ & $-0.025(0.017)$ \\
\hline$P$-value joint & 0.028 & 0.003 & 0.834 & 0.304 & 0.101 & 0.068 & 0.418 & 0.726 & 0.625 & 0.419 & 0.342 \\
\hline Observations & 1606 & 1606 & 1669 & 3928 & 4087 & 4297 & 4315 & 3786 & 3786 & 3786 & 3786 \\
\hline \multicolumn{12}{|l|}{ 1933-1935 } \\
\hline Father & $0.088(0.055)$ & $-0.082(0.056)$ & $-0.200(0.100)^{* *}$ & $-0.231(0.142)$ & $-0.096(0.044)^{* *}$ & $-0.045(0.037)$ & $-0.012(0.046)$ & $-0.029(0.105)$ & $-0.357(0.243)$ & $0.029(0.033)$ & $-0.010(0.029)$ \\
\hline Mother & $-0.109(0.058)^{*}$ & $0.064(0.062)$ & $-0.021(0.119)$ & $-0.077(0.154)$ & $-0.006(0.044)$ & $-0.021(0.042)$ & $0.020(0.050)$ & $-0.048(0.112)$ & $-0.355(0.276)$ & $0.017(0.032)$ & $-0.060(0.036)^{*}$ \\
\hline$P$-value joint & 0.109 & 0.298 & 0.099 & 0.133 & 0.053 & 0.324 & 0.917 & 0.812 & 0.027 & 0.518 & 0.133 \\
\hline Observations & 372 & 327 & 386 & 900 & 946 & 992 & 997 & 868 & 868 & 868 & 868 \\
\hline \multicolumn{12}{|c|}{ 1930-1938, excluding 1934} \\
\hline Father & $0.099(0.032)^{* *}$ & $-0.085(0.028)^{* *}$ & $0.010(0.010)$ & $-0.023(0.084)$ & $0.017(0.025)$ & $-0.029(0.023)$ & $-0.003(0.027)$ & $0.047(0.066)$ & $0.082(0.128)$ & $-0.041(0.020)^{* *}$ & $0.002(0.015)$ \\
\hline Mother & $-0.002(0.004)$ & $-0.032(0.031)$ & $-0.011(0.011)$ & $-0.063(0.091)$ & $-0.043(0.027)$ & $-0.036(0.025)$ & $0.002(0.029)$ & $-0.062(0.068)$ & $-0.092(0.141)$ & $0.026(-0.023)$ & $-0.024(0.016)$ \\
\hline$P$-value joint & 0.006 & 0.001 & 0.483 & 0.697 & 0.276 & 0.057 & 0.994 & 0.599 & 0.719 & 0.109 & 0.334 \\
\hline Observations & 1746 & 1746 & 1816 & 4282 & 4455 & 4695 & 4714 & 4151 & 4151 & 4151 & 4151 \\
\hline
\end{tabular}

Robust standard errors in parentheses; *Significant at $10 \%$ level; ** Significant at $5 \%$ level. For each interval, both the mother and the father are born within those years. Regressions are performed for children living with their natural parents and include sex of child, parity, regional dummies, and parental age. The results for the number of conditions, height-for age- $z$ scores and body mass index are based on observations when the child was 7, 11 and 16 years old. We control for the age of the child and the estimation includes clustered standard errors. Disaggregated analyses are available upon request. 
Table 5a

Parents education and child's health-IV results (full sample).

\begin{tabular}{|c|c|c|c|c|c|c|c|c|c|c|c|}
\hline & $\begin{array}{l}\text { Birth } \\
\text { weight }\end{array}$ & $\begin{array}{l}\text { ow birth } \\
\text { weight }\end{array}$ & $\begin{array}{l}\text { Illness at } \\
\text { birth }\end{array}$ & $\begin{array}{l}\text { Number of } \\
\text { conditions }\end{array}$ & $\begin{array}{l}\text { Having a } \\
\text { chronic } \\
\text { condition }\end{array}$ & $\begin{array}{l}\text { Having a } \\
\text { mental } \\
\text { condition }\end{array}$ & $\begin{array}{l}\text { Having an } \\
\text { acute } \\
\text { condition }\end{array}$ & $\begin{array}{l}\text { Height-for } \\
\text { age-z- } \\
\text { scores }\end{array}$ & $\begin{array}{l}\text { Body mass } \\
\text { index }\end{array}$ & Underweight & Overweight \\
\hline \multicolumn{12}{|l|}{ 1930-1938 } \\
\hline Father & $0.094(0.091)$ & $-0.084(0.079)$ & $0.002(0.027)$ & $0.134(0.209)$ & $0.023(0.060)$ & $0.024(0.055)$ & $0.113(0.073)$ & $0.091(0.151)$ & $-0.301(0.327)$ & $0.009(0.049)$ & $-0.047(0.037)$ \\
\hline$F$-test 1 st stage & 3.41 & 3.41 & 3.81 & 4.17 & 4.19 & 4.81 & 4.88 & 4.16 & 4.16 & 4.16 & 4.16 \\
\hline Mother & $-0.121(0.078)$ & $0.005(0.068)$ & $0.000(0.023)$ & $0.116(0.195)$ & $-0.018(0.055)$ & $0.032(0.0$ & $0.061(0.0$ & $-0.059(0$. & -0.175( & $0.024(C$ & $0.019(0.035)$ \\
\hline$F$-test 1st stage & 8.03 & 8.03 & 8.91 & 7.42 & 7.50 & 7.84 & 7.73 & 7.55 & 7.55 & 7.55 & 7.55 \\
\hline$P$-value joint & 0.253 & 0.551 & 0.997 & 0.556 & 0.907 & 0.676 & 0.132 & 0.810 & 0.460 & 0.822 & 0.450 \\
\hline Observations & 3331 & 3331 & 3459 & 8186 & 8514 & 8921 & 8961 & 7921 & 7921 & 7921 & 7921 \\
\hline \multicolumn{12}{|l|}{$1931-1937$} \\
\hline Father & $0.087(0.140)$ & $-0.030(0.119)$ & $-0.020(0.040)$ & $0.183(0.353)$ & $0.012(0.094)$ & $-0.008(0.085)$ & $0.134(0.128)$ & $0.024(0.257)$ & $-0.285(0.580)$ & $0.058(0.089)$ & $-0.076(0.066)$ \\
\hline$F$-test 1 st stage & 1.43 & 1.43 & 1.66 & 1.63 & 1.75 & 1.93 & 1.95 & 1.59 & 1.59 & 1.59 & 1.59 \\
\hline Mother & $-0.110(0.130)$ & $0.039(0.110)$ & $0.006(0.040)$ & $0.241(0.320)$ & $0.005(0.009)$ & $0.007(0.081)$ & $0.131(0.124)$ & $-0.231(0.234)$ & $-0.418(0.483)$ & $0.068(0.077)$ & $0.007(0.057)$ \\
\hline$F$-test 1st stage & 2.78 & 2.78 & 3.27 & 2.88 & 2.78 & 2.99 & 3.00 & 2.92 & 2.92 & 2.92 & 2.92 \\
\hline$P$-value joint & 0.533 & 0.92 & 0.885 & 0.655 & 0.990 & 0.992 & 0.376 & 0.609 & 0.625 & 0.563 & 0.514 \\
\hline Observations & 2345 & 2345 & 2434 & 5740 & 5964 & 6249 & 6270 & 5543 & 5543 & 5543 & 5543 \\
\hline \multicolumn{12}{|l|}{$1933-1935$} \\
\hline Father & $-0.025(0.105)$ & $-0.007(0.115)$ & $-0.012(0.035)$ & $0.055(0.278)$ & $-0.050(0.075)$ & $0.029(0.068)$ & $0.148(0.086)^{*}$ & $-0.056(0.162)$ & $-0.301(0.454)$ & $0.021(0.056)$ & $-0.056(0.056)$ \\
\hline$F$-test 1 st stage & 4.85 & 4.85 & 4.85 & 3.70 & 3.98 & 4.18 & 4.20 & 3.72 & 3.72 & 3.72 & 3.72 \\
\hline Mother & $-0.240(0.187)$ & $-0.183(0.304)$ & $-0.054(0.060)$ & $-0.525(0.568)$ & $-0.054(0.156)$ & $-0.049(0.136)$ & $-0.065(0.184)$ & $0.105(0.381)$ & $-0.095(0.822)$ & $-0.008(0.108)$ & $-0.017(0.097)$ \\
\hline F-test 1 st stage & 0.68 & 0.68 & 0.85 & 0.51 & 1.10 & 1.02 & 1.02 & 1.15 & 1.15 & 1.15 & 1.15 \\
\hline$P$-value joint & 0.437 & 0.831 & 0.652 & 0.564 & 0.614 & 0.777 & 0.534 & 0.872 & 0.791 & 0.578 & 0.761 \\
\hline Observations & 543 & 543 & 561 & 1321 & 1382 & 1445 & 1450 & 1288 & 1288 & 1288 & 1288 \\
\hline \multicolumn{12}{|c|}{ 1930-1938, excluding 1934} \\
\hline Father & $0.183(0.178)$ & $-0.262(0.172)$ & $-0.006(0.046)$ & $0.161(0.330)$ & $0.045(0.101)$ & $0.080(0.091)$ & $0.102(0.107)$ & $-0.037(0.258)$ & $-0.011(0.525)$ & $0.053(0.085)$ & $-0.034(0.060)$ \\
\hline$F$-test 1 st stage & 3.33 & 3.33 & 4.00 & 4.92 & 4.75 & 5.41 & 5.44 & 4.79 & 4.79 & 4.79 & 4.79 \\
\hline Mother & $-0.201(0.142)$ & $0.126(0.138)$ & $0.035(0.037)$ & $0.059(0.305)$ & $-0.021(0.085)$ & $-0.035(0.081)$ & $-0.028(0.096)$ & $-0.132(0.226)$ & $-0.497(0.467)$ & $0.022(0.073)$ & $-0.033(0.052)$ \\
\hline$F$-test 1 st stage & 8.80 & 8.80 & 10.23 & 10.56 & 10.96 & 11.33 & 11.16 & 11.14 & 11.14 & 11.14 & 11.14 \\
\hline$P$-value joint & 0.362 & 0.317 & 0.544 & 0.688 & 0.901 & 0.664 & 0.470 & 0.668 & 0.396 & 0.536 & 0.399 \\
\hline Observations & 2532 & 2532 & 2629 & 6221 & 6461 & 6778 & 6804 & 6032 & 6032 & 6032 & 6032 \\
\hline
\end{tabular}

children with their natural parents. Extra controls as in $10 \%$ level; 
Table 5b

Parents education and child's health-IV results (Parents finishing at age 14-15).

\begin{tabular}{|c|c|c|c|c|c|c|c|c|c|c|c|}
\hline & $\begin{array}{l}\text { Birth } \\
\text { weight }\end{array}$ & $\begin{array}{l}\text { ow birth } \\
\text { weight }\end{array}$ & $\begin{array}{l}\text { Illness at } \\
\text { birth }\end{array}$ & $\begin{array}{l}\text { Number of } \\
\text { conditions }\end{array}$ & $\begin{array}{l}\text { Having a } \\
\text { chronic } \\
\text { condition }\end{array}$ & $\begin{array}{l}\text { Having a } \\
\text { mental } \\
\text { condition }\end{array}$ & $\begin{array}{l}\text { Having an } \\
\text { acute } \\
\text { condition }\end{array}$ & $\begin{array}{l}\text { Height-for } \\
\text { age-z- } \\
\text { scores }\end{array}$ & $\begin{array}{l}\text { Body mass } \\
\text { index }\end{array}$ & Underweight & Overweight \\
\hline \multicolumn{12}{|l|}{ 1930-1938 } \\
\hline Father & $0.049(0.099)$ & $-0.020(0.087)$ & $-0.018(0.031)$ & $-0.066(0.241)$ & $-0.036(0.073)$ & $-0.007(0.067)$ & $0.080(0.082)$ & $-0.058(0.190)$ & $-0.458(0.391)$ & $0.071(0.063)$ & $-0.458(0.391)$ \\
\hline$F$-test 1 st stage & 41.06 & 41.06 & 43.34 & 39.32 & 40.83 & 41.07 & 41.18 & 36.91 & 36.91 & 36.91 & 36.91 \\
\hline Mother & $-0.145(0.075)^{*}$ & $0.006(0.066)$ & $-0.005(0.023)$ & $0.058(0.184)$ & $-0.058(0.054)$ & $-0.017(0.049)$ & $0.105(0.058)^{*}$ & $-0.145(0.139)$ & $-0.382(0.296)$ & $0.047(0.046)$ & $-0.382(0.296)$ \\
\hline$F$-test 1 st stage & 93.56 & 93.56 & 100.27 & 91.97 & 92.48 & 95.30 & 95.91 & 89.90 & 89.90 & 89.90 & 89.90 \\
\hline$P$-value joint & 0.152 & 0.973 & 0.81 & 0.929 & 0.451 & 0.929 & 0.381 & 0.519 & 0.165 & 0.266 & 0.484 \\
\hline Observations & 2287 & 2287 & 2381 & 5609 & 5845 & 6152 & 6175 & 5415 & 5415 & 5415 & 5415 \\
\hline \multicolumn{12}{|l|}{ 1931-1937 } \\
\hline Father & $0.172(0.138)$ & $-0.065(0.124)$ & $-0.073(0.043)^{*}$ & $-0.036(0.349)$ & $-0.077(0.106)$ & $-0.029(0.097)$ & $0.071(0.117)$ & $-0.018(0.272)$ & $-0.070(0.572)$ & $0.080(0.088)$ & $-0.070(0.572)$ \\
\hline$F$-test 1st stage & 20.13 & 20.13 & 21.11 & 19.19 & 20.36 & 20.28 & 20.45 & 18.38 & 18.38 & 18.38 & 18.38 \\
\hline Mother & $-0.045(0.097)$ & $-0.084(0.087)$ & $0.009(0.030)$ & $0.128(0.245)$ & $-0.038(0.073)$ & $-0.004(0.066)$ & $0.146(0.077)^{*}$ & $-0.214(0.186)$ & $-0.482(0.388)$ & $0.039(0.059)$ & $-0.482(0.388)$ \\
\hline$F$-test 1 st stage & 52.33 & 52.33 & 57.07 & 54.03 & 53.35 & 54.00 & 54.31 & 51.57 & 51.57 & 51.57 & 51.57 \\
\hline$P$-value joint & 0.459 & 0.427 & 0.241 & 0.870 & 0.574 & 0.948 & 0.560 & 0.471 & 0.411 & 0.464 & 0.730 \\
\hline Observations & 1606 & 1606 & 1669 & 3928 & 4087 & 4297 & 4303 & 3786 & 3786 & 3786 & 3786 \\
\hline \multicolumn{12}{|l|}{$1933-1935$} \\
\hline Father & $0.024(0.121)$ & $0.062(0.454)$ & $-0.011(0.039)$ & $0.102(0.305)$ & $-0.123(0.098)$ & $0.012(0.089)$ & $0.094(0.108)$ & $-0.388(0.243)$ & $-0.832(0.574)$ & $0.179(0.083)^{*}$ & $-0.832(0.574)$ \\
\hline$F$-test 1 st stage & 3.21 & 3.21 & 3.85 & 3.24 & 31.93 & 31.46 & 31.75 & 30.10 & 30.10 & 30.10 & 30.10 \\
\hline Mother & $-0.098(0.109)$ & $-0.258(0.275)$ & $-0.030(0.035)$ & $-0.363(0.294)$ & $0.212(0.211)$ & $0.091(0.195)$ & $0.139(0.237)$ & $-0.062(0.216)$ & $1.380(1.121)$ & $-0.240(0.164)$ & $1.380(1.121)$ \\
\hline$F$-test 1 st stage & 11.03 & 11.03 & 12.93 & 13.95 & 9.20 & 8.16 & 7.98 & 8.72 & 8.72 & 8.72 & 8.72 \\
\hline$P$-value joint & 0.656 & 0.615 & 0.554 & 0.457 & 0.304 & 0.837 & 0.768 & 0.107 & 0.284 & 0.400 & 0.518 \\
\hline Observations & 372 & 372 & 386 & 900 & 946 & 992 & 997 & 868 & 868 & 868 & 868 \\
\hline \multicolumn{12}{|c|}{ 1930-1938, excluding 1934} \\
\hline Father & $0.094(0.120)$ & $-0.080(0.104)$ & $-0.013(0.038)$ & $-0.049(0.286)$ & $-0.026(0.087)$ & $-0.004(0.080)$ & $0.086(0.096)$ & $-0.125(0.234)$ & $-0.014(0.455)$ & $0.064(0.077)$ & $-0.027(0.054)$ \\
\hline$F$-test 1 st stage & 64.56 & 64.56 & 69.71 & 60.8 & 63.46 & 64.87 & 65.17 & 55.32 & 55.32 & 55.32 & 55.32 \\
\hline Mother & $-0.153(0.097)$ & $0.000(0.084)$ & $0.031(0.030)$ & $0.026(0.230)$ & $-0.061(0.067)$ & $-0.024(0.061)$ & $0.039(0.072)$ & $-0.316(0.174)$ & $-0.567(0.360)$ & $0.057(0.057)$ & $-0.063(0.041)$ \\
\hline$F$-test 1 st stage & 128.49 & 128.5 & 137.78 & 127.96 & 130.9 & 136.17 & 137.93 & 130.53 & 130.5 & 130.53 & 130.5 \\
\hline$P$-value joint & 0.262 & 0.728 & 0.595 & 0.982 & 0.597 & 0.917 & 0.802 & 0.132 & 0.277 & 0.384 & 0.248 \\
\hline Observations & 1746 & 1746 & 1816 & 4282 & 4455 & 4695 & 4714 & 4151 & 4151 & 4151 & 4151 \\
\hline
\end{tabular}

Robust standard errors in parentheses; *Significant at $10 \%$ level; **Significant at $5 \%$ level. For each interval, both the mother and the father are born within those years. The regressions are performed for those children with their natural parents. Extra controls as in Table 4. 
correlation between year of birth of the father and mother is 0.79 . The correlation for exposure to the reform is 0.53 , while the correlation in years of education is 0.57 .

It is, however, interesting to see how the effects of parental education change if we do separate analyses for fathers and mothers. The results from IV estimation for mothers and fathers are presented in Tables $6 \mathrm{a}$ and $6 \mathrm{~b}$ and $7 \mathrm{a}$ and $7 \mathrm{~b}$, respectively. Most estimated effects for parental education are very small and not significant.

\subsection{Parental outcomes}

We found little evidence for a causal impact of parental education on child heath. In the introduction we have specified a number of channels through which parental education could affect child health. In particular, we mentioned that parental education may affect child health indirectly via parental behavior, parental health and parental financial resources. By investigating the causal impact of education on these parental outcomes, we might be able to rule out whether these parental outcomes might affect child health. The underlying idea is that when parental education for example significantly increases parental financial resources, it is very unlikely that parental financial resources have a substantial impact on child health, given that we do not find any effect of parental education on child health. In Tables 8a and 8b we show results from OLS estimation for the effect of parental education on parental outcomes. Tables $9 \mathrm{a}$ and $9 \mathrm{~b}$ present the IV results.

Education could affect child health through improved prenatal care, for instance because better educated parents have more knowledge of the adverse effects of maternal smoking on infant health. The OLS results in Table 8a show that parental schooling is significantly associated with smoking during pregnancy and whether or not the mother breastfeeds the child. In particular, mothers from higher educated families less often smoke during pregnancy and they breastfeed more often. When we restrict the sample to those parents leaving school at age 14-15, the associations become less strong. Only the positive correlation between mother's education and breastfeeding remains marginally significant. When we instrument parental education by the reform, we see again relatively small $F$-tests for the full sample (Table 9a) and large $F$-tests for the restricted sample (Table 9b). Therefore, in the remainder we restrict attention to the estimation results of the restricted sample in Table 9b. The results show no significant causal effect of parental education on breastfeeding. However, there is a significant positive causal effect of parental education on pregnancy smoking. Mothers from higher educated families thus more often smoke during pregnancy. Recall that our sample contains children born in 1958 and it was not until the Sixties that people became aware of the health risks of smoking (e.g. the Surgeon General Report on health and smoking was released in 1964).

Next, parental education can affect child health via improvements in parental health. Table 8a shows for the full sample significant positive correlations between parental education and parental health, measured by whether or not the parents have chronic illnesses and their anthropometric measures. In particular, parents from higher educated families have fewer chronic illnesses and a lower body mass index. Almost all of these associations disappear when considering only the lower educated parents (Table 8b). And when using IV estimation we do not find any significant effects of parental education on parental health anymore.

Finally, we investigate the effect of parental education on the family's socioeconomic outcomes. The OLS results for the full sample in Table 8a show that mother's education is positively associated with being at work. A higher education of the father is negatively related with employment status of the mother. When we restrict the sample to those with fewer years of education, we no longer find a significant association between education and mother's working status (except for the 1933-1935 birth years). The IV results do not show a significant causal effect of education on the mother's work status.

Table 8a shows that more education is associated with reduced chances of having financial difficulties. In the restricted sample financial difficulties is mainly negatively correlated to the mother's education. This effect remains present after instrumenting parental education (Table $9 \mathrm{~b}$ ). This suggests that more schooling for the mother leads to a causal reduction in the probability of experiencing financial difficulties. ${ }^{6}$ This result is in line with the results of the vast literature on the returns to education. For example, Oreopoulos (2006) finds using the same education reform we use large and significant earnings returns to education. It is generally found that more education leads to higher earnings and that the IV results are generally larger than the OLS results (see for instance the survey of Card, 1999).

The significant causal effects of education on the parents' financial position might have implications for the effect of parental income on child health. Given that parental education has no direct effect on the child health (see Tables 5a and 5b), one might conclude that parental income does not have a large effect on child health. We should note, however, that this claim is based on circumstantial evidence as we do not test this relationship directly. For the population of parents affected by the reform we do not find any effect of education on the parents own health or on parental care. Therefore, we cannot infer anything on the importance of parental health and/or parental care on child health.

\footnotetext{
${ }^{6}$ The financial difficulties variable is derived from the response to a question on whether in the past 12 months the family was hit by serious financial hardship. About $62 \%$ of the families reporting financial difficulties at an interview, report at the next interview not to have financial difficulties anymore. This variable thus seems to reflect the effect of current income, rather than long-run income. See also Section 2 for a discussion about this issue.
} 
Table 6a

Separate analyses for mother's education on child's health-IV results (full sample).

\begin{tabular}{|c|c|c|c|c|c|c|c|c|c|c|c|}
\hline & $\begin{array}{l}\text { Birth } \\
\text { weight }\end{array}$ & $\begin{array}{l}\text { ow birth } \\
\text { weight }\end{array}$ & $\begin{array}{l}\text { Illness at } \\
\text { birth }\end{array}$ & $\begin{array}{l}\text { Number of } \\
\text { conditions }\end{array}$ & $\begin{array}{l}\text { Having a } \\
\text { chronic } \\
\text { condition }\end{array}$ & $\begin{array}{l}\text { Having a } \\
\text { mental } \\
\text { condition }\end{array}$ & $\begin{array}{l}\text { Having an } \\
\text { acute } \\
\text { condition }\end{array}$ & $\begin{array}{l}\text { Height-for } \\
\text { age-z- } \\
\text { scores }\end{array}$ & $\begin{array}{l}\text { Body mass } \\
\text { index }\end{array}$ & Underweight & Overweight \\
\hline \multicolumn{12}{|l|}{ 1930-1938 } \\
\hline Mother & $-0.063(0.071)$ & $-0.010(0.060)$ & $-0.009(0.022)$ & $0.041(0.162)$ & $-0.038(0.050)$ & $-0.012(0.045)$ & $0.041(0.052)$ & $0.063(0.127)$ & $-0.191(0.276)$ & $0.003(0.041)$ & $0.005(0.032)$ \\
\hline$F$-test 1st stage & 14.01 & 14.01 & 15.71 & 16.31 & 15.49 & 16.68 & 17.28 & 15.02 & 14.86 & 14.86 & 14.86 \\
\hline Observations & 5337 & 5337 & 5515 & 13,043 & 13,541 & 14,184 & 13,859 & 12,618 & 12,676 & 12,676 & 12,676 \\
\hline \multicolumn{12}{|l|}{ 1931-1937 } \\
\hline Mother & $-0.029(0.073)$ & $-0.026(0.063)$ & $-0.009(0.023)$ & $0.010(0.164)$ & $-0.064(0.052)$ & $-0.027(0.046)$ & $0.048(0.053)$ & $0.096(0.130)$ & $-0.134(0.278)$ & $0.005(0.041)$ & $0.008(0.032)$ \\
\hline$F$-test 1st stage & 12.65 & 12.65 & 14.59 & 16.27 & 15.29 & 16.56 & 17.50 & 14.36 & 14.51 & 14.51 & 14.51 \\
\hline Observations & 4342 & 12.65 & 4496 & 10,625 & 11,028 & 11,536 & 11,275 & 10,277 & 10,326 & 10,326 & 10,326 \\
\hline \multicolumn{12}{|l|}{ 1933-1935 } \\
\hline Mother & $-0.107(0.067)$ & $-0.084(0.086)$ & $-0.020(0.020)$ & $0.083(0.150)$ & $0.031(0.082)$ & $0.046(0.072)$ & $0.060(0.014)$ & $0.156(0.214)$ & $0.273(0.468)$ & $-0.051(0.069)$ & $0.070(0.058)$ \\
\hline$F$-test 1 st stage & 15.75 & 15.75 & 16.52 & 13.55 & 12.48 & 14.52 & 15.40 & 11.14 & 11.34 & 11.34 & 11.34 \\
\hline Observations & 1908 & 1908 & 1971 & 4678 & 4872 & 5107 & 4980 & 4531 & 4554 & 4554 & 4554 \\
\hline \multicolumn{12}{|c|}{ 1930-1938, excluding 1934} \\
\hline Mother & $-0.073(0.103)$ & $0.078(0.089)$ & $0.011(0.031)$ & $-0.022(0.225)$ & $-0.071(0.068)$ & $-0.399(0.064)$ & $0.020(0.073)$ & $0.059(0.175)$ & $-0.293(0.386)$ & $0.033(0.057)$ & $-0.032(0.043)$ \\
\hline$F$-test 1st stage & 13.59 & 13.59 & 16.08 & 18.43 & 17.69 & 18.21 & 19.03 & 16.29 & 16.41 & 16.41 & 16.41 \\
\hline Observations & 4707 & 4707 & 4861 & 11,460 & 11,882 & 12,459 & 12,177 & 11,075 & 11,126 & 11,126 & 11,126 \\
\hline
\end{tabular}

Robust standard errors in parentheses; *Significant at 10\% level; **Significant at 5\% level. The regressions are performed for those children with their natural parents. Extra controls as in Table 4. 
Table 6b

Separate analyses for mother's education on child's health-IV results (finishing at age 14-15)

\begin{tabular}{|c|c|c|c|c|c|c|c|c|c|c|c|}
\hline & $\begin{array}{l}\text { Birth } \\
\text { weight }\end{array}$ & $\begin{array}{l}\text { ow birth } \\
\text { weight }\end{array}$ & $\begin{array}{l}\text { Illness at } \\
\text { birth }\end{array}$ & $\begin{array}{l}\text { Number of } \\
\text { conditions }\end{array}$ & $\begin{array}{l}\text { Having a } \\
\text { chronic } \\
\text { condition }\end{array}$ & $\begin{array}{l}\text { Having a } \\
\text { mental } \\
\text { condition }\end{array}$ & $\begin{array}{l}\text { Having an } \\
\text { acute } \\
\text { condition }\end{array}$ & $\begin{array}{l}\text { Height-for } \\
\text { age-z- } \\
\text { scores }\end{array}$ & $\begin{array}{l}\text { Body mass } \\
\text { index }\end{array}$ & Underweight & Overweight \\
\hline \multicolumn{12}{|l|}{ 1930-1938 } \\
\hline Mother & $-0.094(0.057)$ & $0.033(0.050)$ & $-0.005(0.019)$ & $-0.007(0.143)$ & $-0.042(0.051)$ & $-0.029(0.038)$ & $0.040(0.045)$ & $-0.061(0.107)$ & $-0.373(0.230)$ & $0.038(0.034)$ & $-0.021(0.027)$ \\
\hline F-test 1st stage & 288.03 & 288.03 & 304.22 & 278.43 & 281.94 & 287.74 & 281.69 & 275.98 & 275.23 & 275.23 & 275.23 \\
\hline Observations & 4094 & 4094 & 4229 & 9952 & 10,345 & 10,863 & 10,609 & 9601 & 9640 & 9640 & 9640 \\
\hline \multicolumn{12}{|l|}{ 1931-1937 } \\
\hline Mother & $-0.057(0.067)$ & $0.011(0.058)$ & $-0.008(0.022)$ & $-0.005(0.167)$ & $-0.071(0.049)$ & $-0.037(0.045)$ & $0.075(0.052)$ & $-0.004(0.126)$ & $-0.359(0.267)$ & $0.040(0.041)$ & $-0.013(0.032)$ \\
\hline F-test 1st stage & 199.04 & 199.04 & 213.82 & 193.29 & 195.28 & 198.30 & 194.17 & 189.81 & 189.69 & 189.69 & 189.69 \\
\hline Observations & 3313 & 3313 & 3426 & 8054 & 8368 & 8773 & 8575 & 7761 & 7794 & 7794 & 7794 \\
\hline \multicolumn{12}{|l|}{ 1933-1935 } \\
\hline Mother & $-0.109(0.047)^{* *}$ & $-0.112(0.105)$ & $-0.015(0.016)$ & $0.053(0.118)$ & $-0.037(0.091)$ & $0.016(0.084)$ & $0.042(0.095)$ & $0.085(0.237)$ & $0.246(0.507)$ & $0.033(0.076)$ & $0.071(0.060)$ \\
\hline$F$-test 1st stage & 102.67 & 102.67 & 112.54 & 99.29 & 97.05 & 100.16 & 97.65 & 92.45 & 94.38 & 94.38 & 94.38 \\
\hline Observations & 1426 & 1426 & 1466 & 3469 & 3617 & 3797 & 3703 & 3335 & 3352 & 3352 & 3352 \\
\hline \multicolumn{12}{|c|}{ 1930-1938, excluding 1934} \\
\hline Mother & $-0.101(0.065)$ & $0.067(0.057)$ & $0.006(0.022)$ & $-0.010(0.164)$ & $-0.044(0.047)$ & $-0.036(0.044)$ & $0.023(0.051)$ & $-0.060(0.121)$ & $-0.409(0.261)$ & $0.035(0.039)$ & $-0.042(0.031)$ \\
\hline F-test 1st stage & 477.98 & 477.98 & 498.82 & 454.92 & 465.59 & 474.60 & 464.75 & 457.42 & 454.03 & 454.03 & 454.03 \\
\hline Observations & 3627 & 3627 & 3747 & 8795 & 9129 & 9600 & 9381 & 8480 & 8513 & 8513 & 8513 \\
\hline
\end{tabular}

Robust standard errors in parentheses; *Significant at 10\% level; **Significant at 5\% level. The regressions are performed for those children with their natural parents. Extra controls as in Table 4 
Table 7a

Separate analyses for father's education on child's health-IV results (full sample).

\begin{tabular}{|c|c|c|c|c|c|c|c|c|c|c|c|}
\hline & $\begin{array}{l}\text { Birth } \\
\text { weight }\end{array}$ & $\begin{array}{l}\text { ow birth } \\
\text { weight }\end{array}$ & $\begin{array}{l}\text { Illness at } \\
\text { birth }\end{array}$ & $\begin{array}{l}\text { Number of } \\
\text { conditions }\end{array}$ & $\begin{array}{l}\text { Having a } \\
\text { chronic } \\
\text { condition }\end{array}$ & $\begin{array}{l}\text { Having a } \\
\text { mental } \\
\text { condition }\end{array}$ & $\begin{array}{l}\text { Having an } \\
\text { acute } \\
\text { condition }\end{array}$ & $\begin{array}{l}\text { Height-for } \\
\text { age-z- } \\
\text { scores }\end{array}$ & $\begin{array}{l}\text { Body mass } \\
\text { index }\end{array}$ & Underweight & Overweight \\
\hline \multicolumn{12}{|l|}{$1930-1938$} \\
\hline Father & $0.034(0.090)$ & $-0.058(0.082)$ & $-0.011(0.028)$ & $0.108(0.224)$ & $0.016(0.067)$ & $0.057(0.061)$ & $0.072(0.064)$ & $-0.043(0.177)$ & $-0.396(0.366)$ & $0.037(0.056)$ & $-0.030(0.041$ \\
\hline$F$-test 1st stage & 5.57 & 5.57 & 6.17 & 6.24 & 6.24 & 7.46 & 7.82 & 5.98 & 6.18 & 6.18 & 6.18 \\
\hline Observations & 3944 & 3944 & 4093 & 9614 & 10,001 & 10,480 & 10,187 & 9291 & 9332 & 9332 & 9332 \\
\hline \multicolumn{12}{|l|}{$1931-1937$} \\
\hline Father & $0.016(0.112)$ & $-0.005(0.102)$ & $-0.035(0.036)$ & $0.219(0.319)$ & $-0.020(0.043)$ & $0.086(0.086)$ & $0.087(0.090)$ & $0.011(0.239)$ & $-0.325(0.502)$ & $0.007(0.074)$ & $-0.030(0.057$ \\
\hline$F$-test 1st stage & 3.92 & 3.92 & 4.10 & 3.54 & 3.61 & 4.28 & 4.35 & 3.39 & 3.49 & 3.49 & 3.49 \\
\hline Observations & 3167 & 3167 & 3286 & 7692 & 7996 & 8379 & 8154 & 7423 & 7457 & 7457 & 7457 \\
\hline \multicolumn{12}{|l|}{ 1933-1935 } \\
\hline Father & $-0.019(0.104)$ & $0.147(0.140)$ & $-0.010(0.033)$ & $0.422(0.355)$ & $0.001(0.131)$ & $0.067(0.120)$ & $0.161(0.141)$ & $0.231(0.309)$ & $-0.589(0.666)$ & $-0.015(0.095)$ & $-0.058(0.075$ \\
\hline$F$-test 1st stage & 6.36 & 6.36 & 4.85 & 4.33 & 4.49 & 5.24 & 5.31 & 5.17 & 5.40 & 5.40 & 5.40 \\
\hline Observations & 1444 & 1444 & 1496 & 3475 & 3618 & 3789 & 3689 & 3362 & 3375 & 3375 & 3375 \\
\hline \multicolumn{12}{|c|}{ 1930-1938, excluding 1934} \\
\hline Father & $0.056(0.101)$ & $-0.090(0.092)$ & $-0.015(0.031)$ & $-0.057(0.243)$ & $0.011(0.074)$ & $0.046(0.066)$ & $0.050(0.069)$ & $-0.118(0.209)$ & $-0.294(0.406)$ & $0.063(0.066)$ & $-0.022(0.046$ \\
\hline$F$-test 1st stage & 8.86 & 8.86 & 10.26 & 10.34 & 10.48 & 12.30 & 12.86 & 9.38 & 9.66 & 9.66 & 9.66 \\
\hline Observations & 3468 & 3468 & 3601 & 8479 & 8826 & 9252 & 8980 & 8219 & 8252 & 8252 & 8252 \\
\hline
\end{tabular}

Robust standard errors in parentheses; *Significant at 10\% level; **Significant at 5\% level. The regressions are performed for those children with their natural parents. Extra controls as in Table 4. 
Table 7b

Separate analyses for father's education on child's health-IV results (finishing at age 14-15).

\begin{tabular}{|c|c|c|c|c|c|c|c|c|c|c|c|}
\hline & $\begin{array}{l}\text { Birth } \\
\text { weight }\end{array}$ & $\begin{array}{l}\text { ow birth } \\
\text { weight }\end{array}$ & $\begin{array}{l}\text { Illness at } \\
\text { birth }\end{array}$ & $\begin{array}{l}\text { Number of } \\
\text { conditions }\end{array}$ & $\begin{array}{l}\text { Having a } \\
\text { chronic } \\
\text { condition }\end{array}$ & $\begin{array}{l}\text { Having a } \\
\text { mental } \\
\text { condition }\end{array}$ & $\begin{array}{l}\text { Having an } \\
\text { acute } \\
\text { condition }\end{array}$ & $\begin{array}{l}\text { Height-for } \\
\text { age-z- } \\
\text { scores }\end{array}$ & $\begin{array}{l}\text { Body mass } \\
\text { index }\end{array}$ & Underweight & Overweight \\
\hline \multicolumn{12}{|l|}{ 1930-1938 } \\
\hline Father & $-0.003(0.084)$ & $0.012(0.076)$ & $-0.010(0.027)$ & $0.053(0.216)$ & $-0.014(0.065)$ & $0.037(0.061)$ & $0.058(0.066)$ & $-0.135(0.175)$ & $-0.412(0.352)$ & $0.091(0.057)$ & $-0.016(0.041)$ \\
\hline F-test 1st stage & 101.86 & 101.86 & 106.91 & 90.45 & 94.20 & 93.14 & 91.47 & 85.51 & 85.41 & 85.41 & 85.41 \\
\hline Observations & 3141 & 3141 & 3266 & 7650 & 7967 & 8373 & 8133 & 7392 & 7423 & 7423 & 7423 \\
\hline \multicolumn{12}{|l|}{ 1931-1937 } \\
\hline Father & $-0.026(0.105)$ & $0.041(0.096)$ & $-0.029(0.033)$ & $0.077(0.279)$ & $-0.059(0.083)$ & $0.054(0.079)$ & $0.054(0.086)$ & $-0.247(0.230)$ & $-0.470(0.459)$ & $0.110(0.073)$ & $-0.016(0.053)$ \\
\hline F-test 1st stage & 61.31 & 61.31 & 62.61 & 53.00 & 55.31 & 54.11 & 52.84 & 48.97 & 48.93 & 48.93 & 48.93 \\
\hline Observations & 2543 & 2543 & 2645 & 6193 & 6437 & 6764 & 6587 & 5973 & 6000 & 6000 & 6000 \\
\hline \multicolumn{12}{|l|}{ 1933-1935 } \\
\hline Father & $-0.009(0.063)$ & $0.338(0.262)$ & $-0.017(0.019)$ & $0.150(0.165)$ & $0.107(0.232)$ & $0.208(0.228)$ & $0.299(0.247)$ & $0.267(0.606)$ & $-2.265(1.448)$ & $0.150(0.207)$ & $-0.133(0.151)$ \\
\hline F-test 1st stage & 16.31 & 16.31 & 14.83 & 12.5 & 11.80 & 11.98 & 12.42 & 10.30 & 10.56 & 10.56 & 10.56 \\
\hline Observations & 1182 & 1182 & 1227 & 2837 & 2957 & 3102 & 3020 & 2735 & 2746 & 2746 & 2746 \\
\hline \multicolumn{12}{|c|}{ 1930-1938, excluding 1934} \\
\hline Father & $0.034(0.091)$ & $-0.011(0.081)$ & $-0.011(0.029)$ & $-0.089(0.229)$ & $-0.028(0.069)$ & $0.021(0.064)$ & $0.042(0.070)$ & $-0.161(0.186)$ & $-0.213(0.372)$ & $0.090(0.060)$ & $-0.003(0.044)$ \\
\hline$F$-test 1st stage & 187.34 & 187.34 & 198.45 & 167.18 & 175.50 & 173.58 & 169.81 & 159.38 & 158.78 & 158.78 & 158.78 \\
\hline Observations & 2764 & 2764 & 2874 & 6751 & 7038 & 7401 & 7177 & 6553 & 6579 & 6579 & 6579 \\
\hline
\end{tabular}

Robust standard errors in parentheses: *Significant at 10\% level; **Significant at $5 \%$ level. The regressions are performed for those children with their natural parents. Extra controls as in Table 4 . 
Table 8a

Parental education on parental variables-OLS results (full sample).

\begin{tabular}{|c|c|c|c|c|c|c|c|c|c|c|c|c|}
\hline & $\begin{array}{l}\text { Maternal } \\
\text { smoking } \\
\text { during } \\
\text { pregnancy }\end{array}$ & Breastfeeding & $\begin{array}{l}\text { Father } \\
\text { illness }\end{array}$ & $\begin{array}{l}\text { Mother } \\
\text { illness }\end{array}$ & $\begin{array}{l}\text { Body mass } \\
\text { index father }\end{array}$ & $\begin{array}{l}\text { Father } \\
\text { under- } \\
\text { weight }\end{array}$ & $\begin{array}{l}\text { Father } \\
\text { overweight }\end{array}$ & $\begin{array}{l}\text { Body mass } \\
\text { index } \\
\text { mother }\end{array}$ & $\begin{array}{l}\text { Mother } \\
\text { under- } \\
\text { weight }\end{array}$ & $\begin{array}{l}\text { Mother } \\
\text { overweight }\end{array}$ & $\begin{array}{l}\text { Mother } \\
\text { works }\end{array}$ & $\begin{array}{l}\text { Financial } \\
\text { difficulties }\end{array}$ \\
\hline \multicolumn{13}{|l|}{ 1930-1938 } \\
\hline Father & $-0.016(0.006)^{* *}$ & $0.025(0.005)^{* *}$ & $-0.008(0.002)^{* *}$ & $-0.004(0.002)^{*}$ & $-0.106(0.042)^{* *}$ & ${ }^{*}-0.002(0.003)$ & $-0.019(0.006)^{* *}$ & $-0.176(0.053)^{* *}$ & $0.010(0.006)^{*}$ & $-0.025(0.005)^{* *}$ & $-0.018(0.005)^{* *}$ & ${ }^{*}-0.009(0.002)^{* *}$ \\
\hline Mother & $-0.024(0.008)^{* *}$ & * $0.016(0.007)^{* *}$ & 0.000 & $-0.001(0.003)$ & $-0.065(0.053)$ & $0.003(0.004)$ & $-0.008(0.008)$ & $-0.101(0.066)$ & $-0.004(0.007)$ & $-0.017(0.006)^{* *}$ & $0.013(0.006)^{* *}$ & $-0.008(0.002)^{* *}$ \\
\hline$P$-value & 0.000 & 0.000 & 0.000 & 0.018 & 0.000 & 0.716 & 0.000 & 0.000 & 0.212 & 0.000 & 0.003 & 0.000 \\
\hline Observations & s 2889 & 2662 & 5966 & 5966 & 2938 & 2938 & 2938 & 2938 & 2938 & 2938 & 8947 & 8906 \\
\hline \multicolumn{13}{|l|}{ 1933-1935 } \\
\hline Father & $-0.023(0.014)^{*}$ & $0.032(0.014)^{* *}$ & $-0.018(0.006)^{* *}$ & $-0.006(0.007)$ & $-0.118(0.114)$ & $-0.002(0.005)$ & $-0.023(0.016)$ & $-0.149(0.138)$ & $0.008(0.015)$ & $-0.031(0.014)^{* *}$ & $-0.007(0.015)$ & $-0.008(0.004)^{*}$ \\
\hline Mother & $-0.004(0.019)$ & $0.004(0.020)$ & $0.002(0.007)$ & $-0.001(0.008)$ & $-0.114(0.132)$ & $-0.008(0.005)$ & $-0.001(0.021)$ & $-0.091(0.159)$ & $-0.009(0.017)$ & $-0.021(0.019)$ & $0.025(0.014)^{*}$ & $-0.014(0.005)^{* *}$ \\
\hline$P$-value & 0.184 & 0.065 & 0.002 & 0.484 & 0.193 & 0.159 & 0.228 & 0.275 & 0.834 & 0.001 & 0.181 & 0.000 \\
\hline Observations & s 468 & 422 & 970 & 970 & 473 & 473 & 473 & 473 & 473 & 473 & 1449 & 1446 \\
\hline \multicolumn{13}{|c|}{ 1930-1938 except 1934} \\
\hline Father & $-0.012(0.007)^{*}$ & $0.022(0.006)^{* *}$ & $-0.008(0.002)^{* *}$ & $-0.003(0.002)$ & $-0.113(0.048)^{* *}$ & $-0.004(0.003)$ & $-0.025(0.007)^{* *}$ & $-0.218(0.060)^{* *}$ & * $0.017(0.007)^{* *}$ & $-0.024(0.005)^{* *}$ & $-0.019(0.006)^{* *}$ & ${ }^{*}-0.008(0.002)^{* *}$ \\
\hline Mother & $-0.028(0.008)^{* *}$ & * $0.020(0.008)^{* *}$ & $0.001(0.003)$ & $0.000(0.003)$ & $-0.037(0.060)$ & $0.004(0.005)$ & $-0.001(0.009)$ & $-0.072(0.075)$ & $-0.007(0.008)$ & $-0.017(0.007)^{* *}$ & $0.016(0.007)^{* *}$ & $-0.009(0.002)^{* *}$ \\
\hline$P$-value & 0.000 & 0.000 & 0.000 & 0.164 & 0.003 & 0.489 & 0.000 & 0.000 & 0.045 & 0.000 & 0.006 & 0.000 \\
\hline Observations & s 2189 & 2019 & 4529 & 4529 & 2227 & 2227 & 2227 & 2227 & 2227 & 2227 & 6794 & 6761 \\
\hline
\end{tabular}


Table 8b

Parental education on parental variables-OLS results (finishing at age 14-15).

\begin{tabular}{|c|c|c|c|c|c|c|c|c|c|c|c|c|}
\hline & $\begin{array}{l}\text { Maternal } \\
\text { smoking } \\
\text { during } \\
\text { pregnancy }\end{array}$ & Breastfeeding & $\begin{array}{l}\text { Father } \\
\text { illness }\end{array}$ & $\begin{array}{l}\text { Mother } \\
\text { illness }\end{array}$ & $\begin{array}{l}\text { Body mass } \\
\text { index father }\end{array}$ & $\begin{array}{l}\text { Father } \\
\text { under- } \\
\text { weight }\end{array}$ & $\begin{array}{l}\text { Father } \\
\text { overweight }\end{array}$ & $\begin{array}{l}\text { Body mass } \\
\text { index } \\
\text { mother }\end{array}$ & $\begin{array}{l}\text { Mother } \\
\text { under- } \\
\text { weight }\end{array}$ & $\begin{array}{l}\text { Mother } \\
\text { overweight }\end{array}$ & $\begin{array}{l}\text { Mother } \\
\text { works }\end{array}$ & $\begin{array}{l}\text { Financial } \\
\text { difficulties }\end{array}$ \\
\hline \multicolumn{13}{|l|}{ 1930-1938 } \\
\hline Father & $-0.017(0.028)$ & $0.003(0.028)$ & $-0.013(0.010)$ & $0.011(0.012)$ & $-0.188(0.178)$ & $0.003(0.013)$ & $-0.015(0.028)$ & $-0.057(0.228)$ & $0.001(0.024)$ & $-0.009(0.025)$ & $-0.015(0.020)$ & $-0.019(0.010)^{*}$ \\
\hline Mother & $0.049(0.031)$ & $0.053(0.031)^{*}$ & $0.010(0.011)$ & $-0.012(0.013)$ & $0.025(0.193)$ & $-0.010(0.014)$ & $0.001(0.031)$ & $-0.175(0.249)$ & $0.016(0.026)$ & $-0.015(0.029)$ & $0.012(0.022)$ & $-0.038(0.011)^{* *}$ \\
\hline$P$-value & 0.272 & 0.175 & 0.405 & 0.518 & 0.559 & 0.764 & 0.849 & 0.691 & 0.803 & 0.756 & 0.714 & 0.000 \\
\hline Observations & 1980 & 1829 & 4098 & 4098 & 2007 & 2007 & 2007 & 2007 & 2007 & 2007 & 6168 & 6139 \\
\hline \multicolumn{13}{|l|}{ 1933-1935 } \\
\hline Father & $0.125(0.062)^{* *}$ & $0.072(0.060)$ & $-0.065(0.026)^{* *}$ & $-0.021(0.025)$ & $-0.366(0.431)$ & $-0.001(0.030)$ & $-0.026(0.065)$ & $-0.593(0.508)$ & $0.073(0.053)$ & $-0.074(0.062)$ & $0.094(0.039)^{* *}$ & $-0.001(0.021)$ \\
\hline Mother & $-0.029(0.073)$ & $0.120(0.068)^{*}$ & $0.057(0.026)^{* *}$ & $0.021(0.026)$ & $-0.643(0.491)$ & $-0.001(0.033)$ & $-0.081(0.075)$ & $-0.187(0.579)$ & $-0.028(0.061)$ & $-0.049(0.074)$ & $-0.033(0.042)$ & $-0.025(0.021)$ \\
\hline$P$-value & 0.124 & 0.044 & 0.025 & 0.635 & 0.150 & 0.996 & 0.381 & 0.361 & 0.384 & 0.221 & 0.061 & 0.447 \\
\hline Observations & 320 & 285 & 667 & 667 & 320 & 320 & 320 & 320 & 320 & 320 & 998 & 996 \\
\hline \multicolumn{13}{|c|}{ 1930-1938 except 1934} \\
\hline Father & $0.007(0.033)$ & $0.022(0.034)$ & $0.001(0.012)$ & $0.016(0.015)$ & $-0.116(0.217)$ & $0.001(0.016)$ & $-0.022(0.034)$ & $-0.009(0.281)$ & $-0.002(0.029)$ & $0.019(0.032)$ & $-0.032(0.024)$ & $-0.021(0.011)^{*}$ \\
\hline Mother & $-0.009(0.037)$ & $0.073(0.037)^{* *}$ & $0.004(0.013)$ & $-0.021(0.015)$ & $0.051(0.238)$ & $-0.011(0.018)$ & $-0.008(0.038)$ & $0.002(0.308)$ & $-0.013(0.032)$ & $-0.006(0.036)$ & $0.021(0.027)$ & $-0.050(0.012)^{* *}$ \\
\hline$P$-value & 0.962 & 0.052 & 0.945 & 0.324 & 0.867 & 0.810 & 0.805 & 0.999 & 0.902 & 0.835 & 0.398 & 0.000 \\
\hline Observations & 1512 & 1396 & 3129 & 3129 & 1534 & 1534 & 1534 & 1534 & 1534 & 1534 & 4708 & 4685 \\
\hline
\end{tabular}

Robust standard errors in parentheses; ${ }^{*}$ Significant at $10 \%$
their natural parents. Extra controls include parental age. 
Table 9a

Parental education on parental variables-IV results (full sample).

\begin{tabular}{|c|c|c|c|c|c|c|c|c|c|c|c|c|}
\hline & $\begin{array}{l}\text { Maternal } \\
\text { smoking } \\
\text { during } \\
\text { pregnancy }\end{array}$ & Breastfeeding & $\begin{array}{l}\text { Father } \\
\text { illness }\end{array}$ & $\begin{array}{l}\text { Mother } \\
\text { illness }\end{array}$ & $\begin{array}{l}\text { Body mass } \\
\text { index father }\end{array}$ & $\begin{array}{l}\text { Father } \\
\text { under- } \\
\text { weight }\end{array}$ & $\begin{array}{l}\text { Father } \\
\text { overweight }\end{array}$ & $\begin{array}{l}\text { Body mass } \\
\text { index } \\
\text { mother }\end{array}$ & $\begin{array}{l}\text { Mother } \\
\text { under- } \\
\text { weight }\end{array}$ & $\begin{array}{l}\text { Mother } \\
\text { overweight }\end{array}$ & $\begin{array}{l}\text { Mother } \\
\text { works }\end{array}$ & $\begin{array}{l}\text { Financial } \\
\text { difficulties }\end{array}$ \\
\hline \multicolumn{13}{|l|}{ 1930-1938 } \\
\hline Father & $0.009(0.078)$ & $-0.039(0.067)$ & $-0.018(0.028)$ & $-0.029(0.028)$ & $0.278(0.533)$ & $0.002(0.040)$ & $0.011(0.083)$ & $0.033(0.661)$ & $0.064(0.073)$ & $-0.044(0.076)$ & $-0.041(0.055)$ & $-0.008(0.029)$ \\
\hline F-test 1st stage & 4.56 & 4.70 & 5.14 & 5.14 & 3.90 & 3.90 & 3.90 & 3.90 & 3.90 & 3.90 & 5.26 & 5.23 \\
\hline Mother & $0.078(0.076)$ & $0.052(0.075)$ & $0.030(0.027)$ & $-0.021(0.029)$ & $0.172(0.470)$ & $-0.065(0.038)^{*}$ & $-0.003(0.072)$ & $0.423(0.583)$ & $0.028(0.065)$ & $0.014(0.067)$ & $-0.021(0.056)$ & $-0.068(0.029)^{* *}$ \\
\hline F-test 1st stage & 7.29 & 5.83 & 7.42 & 7.42 & 7.27 & 7.27 & 7.27 & 7.27 & 7.27 & 7.27 & 7.22 & 7.17 \\
\hline$P$-value & 0.508 & 0.720 & 0.522 & 0.517 & 0.744 & 0.164 & 0.999 & 0.734 & 0.669 & 0.777 & 0.630 & 0.034 \\
\hline Observations & 2889 & 2662 & 5966 & 5966 & 2938 & 2938 & 2938 & 2938 & 2938 & 2938 & 8947 & 8906 \\
\hline \multicolumn{13}{|l|}{ 1933-1935 } \\
\hline Father & $0.004(0.280)$ & 0.204 (0.699) & $-0.015(0.064)$ & $-0.082(0.059)$ & $0.052(0.780)$ & $0.010(0.057)$ & $-0.008(0.130)$ & $0.122(0.990)$ & $-0.056(0.116)$ & $0.067(0.125)$ & $0.169(0.321)$ & $-0.023(0.061)$ \\
\hline$F$-test 1st stage & 3.90 & 3.29 & 5.18 & 5.18 & 3.91 & 3.91 & 3.91 & 3.91 & 3.91 & 3.91 & 5.09 & 5.01 \\
\hline Mother & $0.755(0.987)$ & $0.811(3.216)$ & $-0.126(0.209)$ & $0.056(0.175)$ & $-0.104(1.961)$ & $-0.121(0.154)$ & $-0.117(0.324)$ & $0.767(2.489)$ & $-0.062(0.275)$ & $0.070(0.321)$ & $0.818(1.129)$ & $-0.128(0.217)$ \\
\hline F-test 1st stage & 0.42 & 0.23 & 1.79 & 1.79 & 0.73 & 0.73 & 0.73 & 0.73 & 0.73 & 0.73 & 0.49 & 0.49 \\
\hline$P$-value & 0.721 & 0.958 & 0.833 & 0.327 & 0.996 & 0.714 & 0.936 & 0.948 & 0.868 & 0.854 & 0.751 & 0.833 \\
\hline Observations & 468 & 422 & 970 & 970 & 473 & 473 & 473 & 473 & 473 & 473 & 1449 & 1446 \\
\hline \multicolumn{13}{|c|}{ 1930-1938 except 1934} \\
\hline Father & $0.156(0.144)$ & $-0.060(0.125)$ & $-0.052(0.049)$ & $0.039(0.049)$ & $-0.576(0.997)$ & $0.007(0.070)$ & $0.020(0.148)$ & $-0.069(1.209)$ & $-0.028(0.129)$ & $0.061(0.137)$ & $0.051(0.106)$ & $-0.017(0.049)$ \\
\hline F-test 1 st stage & 5.46 & 5.41 & 13.58 & 13.58 & 4.48 & 4.48 & 4.48 & 4.48 & 4.48 & 4.48 & 5.91 & 5.93 \\
\hline Mother & $-0.033(0.131)$ & $0.200(0.117)^{*}$ & $0.053(0.045)$ & $-0.045(0.045)$ & $0.204(0.865)$ & $-0.068(0.067)$ & $-0.013(0.128)$ & $0.837(1.049)$ & $-0.041(0.114)$ & $0.008(0.120)$ & $-0.182(0.095)^{*}$ & $-0.083(0.044)^{*}$ \\
\hline F-test 1st stage & 11.62 & 9.90 & 12.41 & 12.42 & 10.03 & 10.03 & 10.03 & 10.03 & 10.03 & 10.03 & 11.55 & 11.63 \\
\hline$P$-value & 0.417 & 0.150 & 0.482 & 0.607 & 0.533 & 0.346 & 0.991 & 0.543 & 0.735 & 0.771 & 0.096 & 0.018 \\
\hline Observations & 2189 & 2019 & 4529 & 4529 & 2227 & 2227 & 2227 & 2227 & 2227 & 2227 & 6794 & 6761 \\
\hline
\end{tabular}

Robust standard errors in parentheses; *Significant at 10\% level; **Significant at 5\% level. For each interval, both the mother and the father are born within those years. The regressions are performed for those children with their natural parents. Extra controls include parental age. 
Table 9b

Parental education on parental variables-IV results (finishing at age 14-15).

\begin{tabular}{|c|c|c|c|c|c|c|c|c|c|c|c|c|}
\hline & $\begin{array}{l}\text { Maternal } \\
\text { smoking } \\
\text { during } \\
\text { pregnancy }\end{array}$ & Breastfeeding & $\begin{array}{l}\text { Father } \\
\text { illness }\end{array}$ & $\begin{array}{l}\text { Mother } \\
\text { illness }\end{array}$ & $\begin{array}{l}\text { Body mass } \\
\text { index father }\end{array}$ & $\begin{array}{l}\text { Father } \\
\text { under- } \\
\text { weight }\end{array}$ & $\begin{array}{l}\text { Father } \\
\text { overweight }\end{array}$ & $\begin{array}{l}\text { Body mass } \\
\text { index } \\
\text { mother }\end{array}$ & $\begin{array}{l}\text { Mother } \\
\text { under- } \\
\text { weight }\end{array}$ & $\begin{array}{l}\text { Mother } \\
\text { overweight }\end{array}$ & $\begin{array}{l}\text { Mother } \\
\text { works }\end{array}$ & $\begin{array}{l}\text { Financial } \\
\text { difficulties }\end{array}$ \\
\hline \multicolumn{13}{|l|}{ 1930-1938 } \\
\hline Father & $0.140(0.103)$ & $-0.139(0.095)$ & $-0.023(0.038)$ & $0.041(0.038)$ & $0.496(0.670)$ & $-0.018(0.051)$ & $0.024(0.106)$ & $0.173(0.858)$ & $-0.106(0.089)$ & $0.045(0.097)$ & $0.055(0.069)$ & $-0.020(0.037)$ \\
\hline F-test 1st stage & 34.95 & 35.48 & 39.92 & 39.92 & 31.96 & 31.96 & 31.96 & 31.96 & 31.96 & 31.96 & 42.25 & 42.02 \\
\hline Mother & $0.155(0.074)^{* *}$ & $0.052(0.072)$ & $0.043(0.027)$ & $0.002(0.028)$ & $0.263(0.474)$ & $-0.042(0.037)$ & $0.018(0.074)$ & $0.274(0.607)$ & $0.031(0.065)$ & $-0.009(0.069)$ & $-0.024(0.052)$ & $-0.052(0.027)^{*}$ \\
\hline F-test 1st stage & 88.53 & 85.09 & 95.81 & 95.81 & 83.32 & 83.32 & 83.32 & 83.31 & 83.31 & 83.31 & 97.27 & 96.52 \\
\hline$P$-value & 0.021 & 0.295 & 0.279 & 0.551 & 0.593 & 0.373 & 0.934 & 0.866 & 0.470 & 0.873 & 0.688 & 0.111 \\
\hline Observations & 1980 & 1829 & 4098 & 4098 & 2007 & 2007 & 2007 & 2007 & 2007 & 2007 & 6168 & 6139 \\
\hline \multicolumn{13}{|l|}{ 1933-1935 } \\
\hline Father & $-0.928(1.013)$ & $-0.367(0.714)$ & $0.142(0.272)$ & $-0.069(0.285)$ & $3.547(5.738)$ & $-0.086(0.284)$ & $0.425(0.815)$ & $0.818(6.080)$ & $-0.412(0.687)$ & $0.038(0.721)$ & $-0.453(0.483)$ & $0.020(0.214)$ \\
\hline F-test 1st stage & 2.46 & 2.61 & 30.67 & 30.67 & 2.12 & 2.12 & 2.12 & 2.12 & 2.12 & 2.12 & 31.52 & 31.46 \\
\hline Mother & $1.120(0.658)^{*}$ & $0.504(0.459)$ & $-0.051(0.143)$ & $0.118(0.152)$ & $-1.670(3.155)$ & $-0.082(0.176)$ & $-0.325(0.449)$ & $-0.852(3.343)$ & $0.280(0.372)$ & $0.031(0.407)$ & $0.404(0.284)$ & $-0.059(0.130)$ \\
\hline F-test 1st stage & 7.92 & 7.49 & 54.78 & 54.78 & 8.68 & 8.68 & 8.68 & 8.68 & 8.68 & 8.68 & 53.99 & 53.70 \\
\hline$P$-value & 0.194 & 0.472 & 0.870 & 0.680 & 0.823 & 0.656 & 0.769 & 0.965 & 0.749 & 0.984 & 0.362 & 0.860 \\
\hline Observations & 320 & 285 & 667 & 667 & 320 & 320 & 320 & 320 & 320 & 320 & 998 & 996 \\
\hline \multicolumn{13}{|c|}{ 1930-1938 except 1934} \\
\hline Father & $0.252(0.122)^{* *}$ & $-0.267(0.112)$ & $-0.045(0.044)$ & $0.019(0.044)$ & $0.651(0.790)$ & $-0.015(0.059)$ & $0.014(0.124)$ & $0.203(1.015)$ & $-0.111(0.103)$ & $0.051(0.113)$ & $0.135(0.082)$ & $-0.041(0.042)$ \\
\hline F-test 1st stage & 54.64 & 54.15 & 62.79 & 62.79 & 51.30 & 51.30 & 51.30 & 51.30 & 51.30 & 51.30 & 67.06 & 66.54 \\
\hline Mother & $0.108(0.093)$ & $0.104(0.086)$ & $0.039(0.035)$ & $-0.014(0.034)$ & $0.794(0.609)$ & $-0.029(0.049)$ & $0.083(0.095)$ & $0.785(0.783)$ & $-0.028(0.083)$ & $0.039(0.088)$ & $-0.097(0.067)$ & $-0.077(0.033)^{* *}$ \\
\hline F-test 1st stage & 125.71 & 127.16 & 136.63 & 136.63 & 111.83 & 111.83 & 111.83 & 111.83 & 111.83 & 111.83 & 140.45 & 139.11 \\
\hline$P$-value & 0.031 & 0.478 & 0.403 & 0.866 & 0.225 & 0.723 & 0.648 & 0.552 & 0.460 & 0.768 & 0.136 & 0.023 \\
\hline Observations & 1512 & 1396 & 3129 & 3129 & 1534 & 1534 & 1534 & 1534 & 1534 & 1534 & 4708 & 4685 \\
\hline
\end{tabular}

Robust standard errors in parentheses; ${ }^{*}$ Significant at $10 \%$ level; ${ }^{* *}$ Significant at $5 \%$ level. For each interval, both the mother and the father are born within those years. The regressions are performed for those children with their natural parents. Extra controls include parental age. 


\section{Discussion and conclusion}

We examined the intergenerational effects of education on child health. As in most of the empirical literature, our data shows a strong positive association between parental socioeconomic status and child health. To investigate the causality of the relationship, we have exploited exogenous variation in parental educational due to a schooling reform on the minimum school leaving age. We have shown that the schooling reform only affected the educational decisions of individuals at the lower end of the educational distribution. In particular, about 50\% of all individuals in a birth cohort were affected. The education reform appears to have had a substantial positive effect on time in schooling. For males additional schooling can be as high as 0.6 years, for females this is 0.7 years. Our results provide little evidence of a direct causal effect of parental education on child health. There is however more robust evidence of the positive effect of increasing education on living standards since an extra year of schooling decreases the household's financial difficulties. This finding is in line with findings in related research. Increasing the minimum school leaving age seems effective in reducing inequalities in education and income. However, increasing the level of schooling at the bottom of the educational distribution does not improve the parental health and their offspring's health outcomes. The intergenerational mobility of health does seem unaffected by varying minimum school leaving ages. This might be explained by our finding that for the population of parents affected by the reform parental care remained unchanged after the increased education.

Our findings are line with finding from the literature on the intergenerational transmission of education. Black et al. (2005) use a change in the educational system in Norway to assess the causal effect of parental education on the child's education. They also do not find a causal effect from parental education. They conclude from their findings that the intergenerational correlation in education is due to family circumstances and/or inherited ability. This may also be the case for child health.

It is interesting to compare our findings to two studies on the intergenerational effects of education on child health. Currie and Moretti (2003) find significant improvement of infant health for women attending College. This seems to contrast our findings. However, they argue that the improvements in child health come from increases in prenatal care and reduced smoking due to the higher education of the mother. We did not find any changes in prenatal behavior or child care due to the increased schooling. Our results are completely in line with McCrary and Royer (2006). They exploit discontinuities in school entry policies. In their set up the discontinuities can lead to $0.14-0.25$ fewer years of education for those born beyond the school entry date. This change is substantially smaller than the changes in our sample induced by the reform. They examine the effect of education for those mothers giving birth before the age of 23 and find limited returns to education. They argue that this is because they focus on a sample of low educated women at risk of dropping out of school (like in our sample). Alternatively, the differences in results between Currie and Moretti (2003) on the one hand and our study and McCrary and Royer (2006) on the other hand can be explained by the fact that the type of policy is different: our study focuses on a policy manipulating time of exit while Currie and Moretti (2003) look at a policy promoting College entrance. ${ }^{7}$ The policies thus interfere at different margins of the parental educational distribution. One might take from combining the studies that positive intergenerational effects on child health appear when the parents reach a sufficiently high educational level. Besides most of those affected by the 1947 reform went into general secondary education and one could argue that because of this the value added of the additional year of schooling was very small. So, the quality of education rather than the quantity of education may be important.

\section{Acknowledgement}

We acknowledge the valuable comments of two anonymous referees.

\section{Appendix A. Supplementary data}

Supplementary data associated with this article can be found, in the online version, at doi:10.1016/j.jhealeco.2008.08.003.

\section{References}

Arendt, J.N., 2005. Does education cause better health? A panel data analysis using school reforms for identification. Economics of Education Review 24, 149-160.

Behrman, J.R., Rosenzweig, M.R., 2002. Does increasing women's schooling raise the schooling of the next generation? American Economic Review 92, 323-334.

Black, S., Devereux, P., Salvanes, K., 2005. Why the apple doesn't fall far: understanding the intergenerational transmission of education. American Economic Review 95, 437-449.

Card, D., 1999. The causal effect of education on earnings. In: Ashenfelter, O.C., Card, D. (Eds.), Handbook of Labor Economics, vol. 3A. North-Holland.

Case, A., Lubotsky, M., Paxson, C., 2002. Economic status and health in childhood: the origins of the gradient. American Economic Review 92, $1308-1334$.

Case, A., Fertig, A., Paxson, C., 2005. The lasting impact on childhood health and circumstance. Journal of Health Economics 24, 365-389.

Chevalier, A., Harmon, C., O’Sullivan, V., Walker, I., 2005. The impact of parental income and education on the schooling of their children. IZA Discussion Papers Series, Discussion paper no. 1496.

Cole, T.J., Bellizzi, M.C., Flegal, K.M., Dietz, W.H., 2000. Establishing a standard definition for child overweight and obesity worldwide: international survey. British Medical Journal 320, 1240-1243.

\footnotetext{
7 McCrary and Royer (2006) is more similar to our study as they also consider low educated mothers and they focus on the time in school of these women.
} 
Currie, J., Moretti, E., 2003. Mother's education and the intergenerational transmission of human capital: evidence from college openings. Quarterly Journal of Economics 118, 1495-1532.

Currie, A., Shields, M.A., Wheatley-Price, S., 2007. The child health/family income gradient: evidence from England. Journal of Health Economics $26,213-232$.

Cutler, D.M., Lleras-Muney, A., in press. Education and health: evaluating theories and evidence. In: House, J., Schoeni, R., Kaplan, G., Pollack, H. (Eds.), The Effects of Social and Economic Policy on Health, Russell Sage Press.

Doyle, O., Harmon, C., Walker, I., 2005. The impact of parental income and education on the health of their children, IZA Discussion Paper Series, Discussion paper no. 1832.

Galindo-Rueda, F., 2003. The Intergenerational Effect of Parental Schooling: Evidence from the British 1947 School Leaving Reform. Centre for Economic Performance, Mimeo.

Hahn, J., Todd, P., van der Klaauw, W., 2001. Identification and estimation of treatment effects with a regression-discontinuity design. Econometrica 69, 201-209.

Harmon, C., Walker, I., 1995. Estimates of the economic return to schooling for the United Kingdom. American Economic Review 85, $1278-1296$.

Holmlund, H., Lindahl, M., Plug, E., 2008. Estimating Intergenerational Schooling Effects: A Comparison of Methods. IZA Discussion Papers Series, Discussion Paper no. 3630

Imbens, G.W., Angrist, J.D., 1994. Identification and estimation of local average treatment effects. Econometrica 62, 467-475.

Leon, D.A., Lithell, H.O., Vågerö, D., Koupilová, I., Mohsen, R., Berglund, L., Lithell, U.-B., McKeigne, P.M., 1998. Reduced fetal growth rate and increased risk of death from ischaemic heart disease: Cohort Study of 15000 Swedish men and women born 1915-29. British Medical Journal 317, 241-245.

Lleras-Muney, A., 2005. The relationship between education and adult mortality in the United States. Review of Economic Studies 72, 189-221.

McCrary, J., Royer, H., 2006. The Effect of Female Education on Fertility and Infant Health: Evidence from School Entry Policies Using Exact Date of Birth, University of Michigan, Working Paper.

Meghir, C., Palme, M., 2005. Educational reform, ability and parental background. American Economic Review 95, 414-424.

Oreopoulos, P., 2006. Estimating average and local average treatment effects of education when compulsory schooling laws really matter. American Economic Review 96, 152-175.

Oreopoulos, P., Page, M.E., Stevens, A.H., 2006. The intergenerational effects of compulsory schooling. Journal of Labor Economics 24, 729-760.

Pischke, J.-S., von Wachter, T., 2008. Zero returns to compulsory schooling in Germany: evidence and interpretation. Review of Economics and Statistics 90, 592-598.

Power, C., Peckham, C. 1987. Childhood morbidity and adult ill-health, National child Development Study User Support Group, Working paper no. 37.

Staiger, D., Stock, J.H., 1997. Instrumental variables regression with weak instruments. Econometrica 65, 557-586.

Van den Berg, G.J., Lindeboom, M., Portrait, F., 2006. Economic conditions early in life and individual mortality. American Economic Review 96, 290-302. 